NBER WORKING PAPER SERIES

\title{
GLOBAL RETAIL LENDING IN THE AFTERMATH OF THE US FINANCIAL CRISIS: DISTINGUISHING BETWEEN SUPPLY AND DEMAND EFFECTS
}

\author{
Manju Puri \\ Jörg Rocholl \\ Sascha Steffen \\ Working Paper 16967 \\ http://www.nber.org/papers/w16967
}

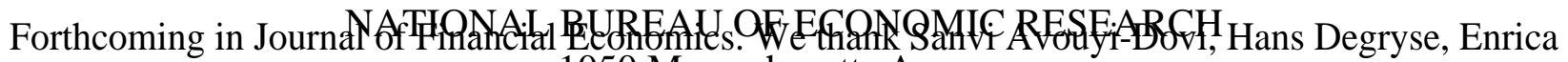
Detragiache, Valeriya Dinger, Andtew EMHass

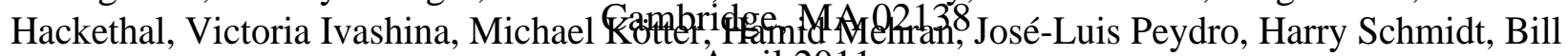
Schwert (the editor), Berk Sensoy, David SrAptil(the1 referee), Phil Strahan, Marcel Tyrell, Vikrant Vig, Mark Wahrenburg, as well as seminar participants at the 2010 Western Finance Association (WFA) meetings, 2010 Financial Intermediation Research Society (FIRS) conference, 2010 Interdisciplinary Center (IDC) Herzliya conference, 2010 American Finance Association (AFA) meetings, 2009 UniCredit conference in Rome, 2009 Federal Deposit Insurance Corporation's Center for Financial Research (FDIC CFR) workshop, second Centre for Economic Policy Research and the European Banking Center and the University of Antwerp (CEPR-EBC-UA) Conference on Competition in Banking Markets, 2009 European Central Bank and the Center for Financial Studies (ECB-CFS) Research Network Conference, 2009 CEPR meetings in Gerzensee, Business Models in Banking Conference at Bocconi, FDIC Ninth Annual Bank Research Conference, Recent Developments in Consumer Credit and Payments Conference at Federal Reserve Bank Philadelphia, German Finance Association annual meeting, Bruegel, Deutsche Bundesbank, Duke University, ESMT, HEC Lausanne, Tilburg University, University of Amsterdam, University of Mannheim, and University of North Carolina. We are grateful to the FDIC for funding and to the German Savings Bank Association for access to data. Jörg Rocholl acknowledges support from the Peter-Curtius Foundation. Sascha Steffen acknowledges support from Deutsche Forschungsgemeinschaft (Grant Ste 1836/1-1). The views expressed herein are those of the authors and do not necessarily reflect the views of the National Bureau of Economic Research.

NBER working papers are circulated for discussion and comment purposes. They have not been peerreviewed or been subject to the review by the NBER Board of Directors that accompanies official NBER publications.

(C) 2011 by Manju Puri, Jörg Rocholl, and Sascha Steffen. All rights reserved. Short sections of text, not to exceed two paragraphs, may be quoted without explicit permission provided that full credit, including $\odot$ notice, is given to the source. 
Global retail lending in the aftermath of the US financial crisis: Distinguishing between supply and demand effects Manju Puri, Jörg Rocholl, and Sascha Steffen

NBER Working Paper No. 16967

April 2011

JEL No. F34,G01,G21

\begin{abstract}
This paper examines the broader effects of the US financial crisis on global lending to retail customers. In particular we examine retail bank lending in Germany using a unique data set of German savings banks during the period 2006 through 2008 for which we have the universe of loan applications and loans granted. Our experimental setting allows us to distinguish between savings banks affected by the US financial crisis through their holdings in Landesbanken with substantial subprime exposure and unaffected savings banks. The data enable us to distinguish between demand and supply side effects of bank lending and find that the US financial crisis induced a contraction in the supply of retail lending in Germany. While demand for loans goes down, it is not substantially different for the affected and nonaffected banks. More important, we find evidence of a significant supply side effect in that the affected banks reject substantially more loan applications than nonaffected banks. This result is particularly strong for smaller and more liquidity-constrained banks as well as for mortgage as compared with consumer loans. We also find that bank-depositor relationships help mitigate these supply side effects.
\end{abstract}

Manju Puri

Fuqua School of Business

Duke University

1 Towerview Drive, Box 90120

Durham, NC 27708-0120

and NBER

mpuri@duke.edu

Jörg Rocholl

European School of Management and Technology

Schlossplatz 1

D-10178 Berlin

rocholl@esmt.org
Sascha Steffen

University of Mannheim

L5, 2

D-68131 Mannheim

steffen@bank.bwl.uni-mannheim.de 


\section{Introduction}

Krugman and Obstfeld (2008) argue that “one of the most pervasive features of today's commercial banking industry is that banking activities have become globalized" (p.600). An important question is whether the growing trend in globalization in banking results in events such as the US financial crisis affecting the real economy in other countries through the bank lending channel. ${ }^{1}$ In particular, it is important to understand the implications for retail customers who are a major driver of economic spending and who have been the focus of much of regulators' attention in dealing with the current crisis.

The goal of this paper is thus to understand if subsequent to a substantial adverse credit shock such as the US financial crisis there is an important global supply side effect for retail customers even in banks that are mandated to serve only local customers and countries that are affected only indirectly by the crisis. The paper builds on the existing literature on nonmonetary transmissions of shocks to the lending sector (e.g., Bernanke, 1983; and Bernanke and Blinder, 1988, 1992) and financial contagion (e.g., Allen and Gale, 2000) and asks the following questions. Does the financial crisis affect lending practices in foreign countries with stable economic performance? Do the worst-hit banks in these countries reduce their lending? Does the domestic retail customer, e.g., the construction worker in Germany, face credit rationing from his local bank as a result? Or is the decreased credit driven by reduced loan applications on the demand side by consumers? If there are supply effects, which type of credit is affected most? Do bank-depositor relations help mitigate these effects? These questions are particularly important in the context of retail lending on which there has been relatively little research.

In this paper we address these questions by taking advantage of a unique database. Our experimental setting is that of German savings banks, which provide an ideal laboratory to analyze the question of supply side effects on retail customers. Savings banks in Germany are particularly interesting to examine as they are mandated by law to serve only their respective local customers and thus operate in precisely and narrowly defined geographic regions,

\footnotetext{
${ }^{1}$ Another event along these lines is the spring 2010 sovereign debt crisis in some European countries to which European banks in particular have a significant exposure.
} 
following a version of narrow banking. Total lending and corporate lending by savings banks in Germany kept increasing even after the beginning of the financial crisis in 2007. However, retail lending by savings banks showed a slow and continuous decrease. This raises the question of whether the decline in retail credit is due to savings banks rejecting more loan applications. For the savings banks we have the universe of loan applications made, along with the credit scoring. We also know which loan applications were granted and which were turned down. Hence we are able to directly distinguish between supply and demand effects. This differentiation is important from a policy perspective. We are able to assess the implications of credit rationing for retail customers on which there has been relatively little empirical work. Further, our data set also allows us to speak to the kinds of loans that are affected most and also assess if relations help mitigate credit rationing in such situations.

The German economy showed reasonable growth and a record-low level of unemployment until 2008. Furthermore, the German housing market did not experience the significant increase and rapid decline in prices that occurred in US and other European markets and thus did not affect German banks. At the same time, some of the German regional banks (Landesbanken) had large exposure to the US subprime market and were substantially hit in the wake of the financial crisis. These regional banks are in turn owned by the savings banks, which had to make guarantees or equity injections into the affected Landesbanken. We thus have a natural experiment in which we can distinguish between affected savings banks (that own Landesbanken affected by the financial crisis) and other savings banks.

Our empirical strategy proceeds as follows. Using a comprehensive data set of consumer loans for the July 2006 through June 2008 period, we examine whether banks that are affected at the onset of the financial crisis reduce consumer lending more relative to nonaffected banks. We are able to distinguish between demand and supply effects. While we find an overall decrease in demand for consumer loans after the beginning of the financial crisis, we do not find significant differences in demand as measured by applications to affected versus unaffected savings banks. More important, we do, however, find evidence for a supply side effect on credit after the onset of the financial crisis. In particular, we find the average rejection rate of affected savings banks is significantly higher than of nonaffected savings banks. This result holds particularly true for 
smaller and more liquidity-constrained banks. Further, we find that this effect is stronger for mortgage as compared with consumer loans. Finally, we consider the change in rejection rates at affected banks after the beginning of the financial crisis by rating class. We find that the rejection rates significantly increase for each rating class and, in particular, for the worst rating classes, but the overall distribution of accepted loans does not change.

We next analyze whether bank-depositor relations affect supply side effects in lending. We are interested in whether borrowers at affected banks who have a prior relationship with this bank are more likely to receive a loan after the start of the financial crisis. We show a clear benefit to bank-depositor relations resulting in significantly higher acceptance rates of loan applications by customers in the absence of the financial crisis. Further, while affected banks significantly reduce their acceptance rates during the financial crisis, we find relationships help mitigate the supply side effects on bank lending. Customers with relationships with the affected bank are less likely to have their loans rejected as compared with new customers. Our results are robust to multiple specifications.

Our paper adds to the growing literature on the effects of the globalization of banking. Peek and Rosengren (1997), Rajan and Zingales (2003), Berger, Dai, Ongena, and Smith (2003), and Mian (2006) analyze the opportunities and limits of banks entering foreign countries and the effect of foreign banks lending to corporate firms. Relatively little research has been done on the effect of globalization on retail lending, and on the effect of small savings banks taking on international exposure on the bank's local borrowers in the bank's home country. Our paper provides evidence on this count. We show that borrowers are affected through a direct banking channel when their local bank experiences an adverse shock even when the local bank itself practices narrow banking but has exposure in a foreign country through its ownership structure. Our paper also adds to the growing work that tries to understand the real effects of financial crises. Ivashina and Scharfstein (2010) and Chari, Christiano, and Kehoe (2008) study bank lending to corporate firms in the US after the onset of the financial crisis. Gan (2007) and Duchin, Ozbas, and Sensoy (2010) show a decline in corporate investments as a consequence of tightened credit supply. Our paper presents complementary evidence on the consumer, or retail side, using an experimental setting that enables us to directly distinguish between the demand and supply 
effects of the financial crisis. Insofar as retail customers do not have access to other financing sources in the same way as corporate customers who can also access public debt or equity markets, if there is a supply side effect of bank lending, it is likely to be particularly important for retail customers. We find evidence of supply side effect on retail lending after the beginning of the financial crisis that is stronger for certain kinds of loans and mitigated by consumer-bank relationships. More generally, our paper adds to the broader literature on credit rationing (Stiglitz and Weiss, 1981). While credit rationing has been studied for corporations, limited work examines credit rationing for retail loans, especially in times of financial crises. Finally, our paper also speaks to the literature on relationships. While bank-firm relations are generally considered important (see Petersen and Rajan, 1994; and Berger and Udell, 1995), the importance of bank relations for retail customers has received far less attention. Our evidence suggests that bank-depositor relationships are important in mitigating credit rationing effects in times of financial crises.

The rest of the paper is as follows. Section 2 gives the institutional background. Section 3 explains the empirical strategy and proposed methodology. Section 4 describes the data. Section 5 gives the empirical results. Section 6 does robustness checks. Section 7 concludes.

\section{Institutional background and data}

We start by describing the institutional background and the data that we use in our paper.

\subsection{Savings banks as the owners and guarantors of Landesbanken}

Savings banks and Landesbanken belong to the group of public banks, which form one of the three pillars of the German banking system. The other two pillars are private banks and cooperative banks. There are 11 Landesbanken in Germany, which cover different federal states. Table 1 provides an overview of the 11 Landesbanken and their respective owners. Each Landesbank is owned by the federal state (Bundesland) in which it is located as well as the savings banks associations in the state, which represent all savings banks in federal states. The ownership of a Landesbank by a specific savings bank is thus solely determined by the regional 
location of this savings bank. A savings bank cannot become the owner of a different Landesbank in any other state. Table 1 shows that savings banks own a substantial share of their respective Landesbanken. For example, the savings banks association of Bavaria (Sparkassenverband Bayern) holds 50\% of Bayern LB, which is the Landesbank in Bavaria.

\section{INSERT TABLE 1 HERE}

Savings banks are required to provide financial services for customers in their municipality, which is referred to as the regional principle. This principle implies that savings banks are allowed to generate business only in the municipality in which they operate, but not to expand to other regions. In fact, consumer loan applications are rejected if the consumers live in a different municipality. Savings banks have the explicit legal mandate not to maximize profits, but to provide financial access to the community in which they operate and to customers without access to financial services with other financial institutions. The business model of savings banks can thus be regarded as a form of narrow banking in which deposits are collected from local customers and then lent only to local customers, while no out-of-area activities are pursued. ${ }^{2}$ Their traditional customers have thus been small and medium-size enterprises as well as retail customers, and they require low hurdles for the opening of consumer accounts among all German banks. In several federal states, savings banks are even legally required to open a current account for every applicant on a deposit basis.

While Landesbanken differ from each other in their exact scope and scale, they have three common features (Moody's, 2004b). First, Landesbanken serve as the house bank to the federal state in which they are located, e.g., by financing infrastructure projects. Second, Landesbanken cooperate with the savings banks in their region, serve as their clearing bank, and support them in wholesale business such as syndicated lending or underwriting. Third, Landesbanken act as commercial banks.

\footnotetext{
${ }^{2}$ Kobayakawa and Nakamura (2000) survey and examine different proposals of narrow banking. They show that the content of these proposals varies substantially although they all use the same expression. In particular, some authors view narrow banks as institutions that invest only in safe assets, while other authors would also allow these banks to lend to small firms. The definition we follow refers to the latter. Savings banks are allowed to give loans to retail and mainly small corporate customers in their local community. At the same time, they are not allowed to pursue investment banking activities so that their exposure to the US subprime markets stems only from their ownership of the Landesbanken.
} 
Debt by the German public bank sector, i.e., by savings banks and Landesbanken, was traditionally formally guaranteed by the respective public owners. The European Commission and the Federal Republic of Germany finally agreed in 2001 to abolish any formal guarantee by public owners, as it was felt that this put privately owned banks at a disadvantage. Thus, any debt obligation issued by German public banks after July 2005 is not publicly guaranteed in a formal way. This is explicitly ruled in the federal states' savings banks laws. Public ownership and political motivations still play a substantial role in the Landesbanken. For example, politicians chair the supervisory boards of the Landesbanken and are heavily involved in the appointment of the management of the Landesbanken.

But even without a formal guarantee by their respective public owners, additional support mechanisms exist for savings banks and Landesbanken. Moody’s (2004b) considers these mechanisms as "giving . . . a wider mandate than a mere deposit protection scheme, thereby protecting all liabilities of its members and not just deposits” (p.4). For the Landesbanken, in principle, there are two support mechanisms, apart from the implicit government guarantee that would prevent a systemically relevant bank from becoming insolvent. First, a Landesbank can rely on horizontal support from the other Landesbanken. However, Moody’s (2004b) is skeptical of this first type of support mechanism and argues that "we believe that both the willingness and capacity of Landesbanken to support each other beyond the means already available in the fund is questionable” (p.12). Likewise, Fitch (2007) does not incorporate the horizontal support mechanism in its ratings. ${ }^{3}$

Second, a Landesbank can rely on vertical support from the savings banks in its region. This support mechanism can take two forms: an informal understanding or a formalized agreement. These formalized agreements between Landesbanken and savings bank associations have been created in eight of the 16 German federal states: Bavaria, Hesse, Lower Saxony, MecklenburgWestern Pomerania, North Rhine-Westphalia, Saxony, Saxony-Anhalt, and Thuringia, (see Fitch, 2007). But even if no formal agreement between Landesbanken and savings banks exist,

\footnotetext{
${ }^{3}$ Fitch (2007) says: "Hence, for Landesbanks Fitch ... does not factor horizontal support into its Landesbank ratings” (p.8).
} 
the general view is that savings banks would rescue their respective Landesbank. Savings banks are not only owners of Landesbanken, but they also profit from the wide range of wholesale business offered by the Landesbank and are likely to want to protect the brand name. Thus, Moody's (2004b) argues that "savings banks would, for the foreseeable future, support Landesbanken” (p.14) and incorporates this support mechanism as a rating floor for public banks. Overall, risks in the business models of Landesbanken are considered to be larger than risks in the narrow banking model of local savings banks, which profit from their strong presence in retail banking.

In conclusion, Landesbanken can credibly rely on several support mechanisms. While they lack a formal guarantee by their public owners for recently issued debt obligations, they can still rely on this guarantee for debt obligations issued before 2001 as well as those issued between 2001 and 2005 and maturing before 2015. In addition, they can rely on formalized vertical support mechanisms from their savings banks as one of their major owners.

\subsection{The savings banks' support for Landesbanken in the financial crisis}

Germany's economy experienced a growth of 2.5\% in 2007 and expanded even for a substantial part of 2008. Overall gross domestic product (GDP) growth for 2008 amounted to 1.3\% and became slightly negative only in the second quarter of 2008, while unemployment reached its 16-year low in October 2008. Furthermore and in contrast to many other countries, house prices in Germany remained constant over the decade preceding the US crisis. In fact, according to the OECD (2008), even in nominal terms German housing prices did not increase in any single year since 1999. As a consequence, German banks have not been affected by a bubble and subsequent burst in the national real estate market. However, German banks invested substantially in the US and are thus affected by the financial crisis that started in the US subprime real estate market. The German banks with the largest exposure in this segment in 2007 were IKB Deutsche Industriebank, which was then partially publicly owned, and Sachsen LB, which was the smallest of the German Landesbanken with total assets of $€ 68$ billion. The exposure for each of these two banks amounted to more than $€ 16$ billion and thus even exceeded the exposure of significantly larger banks such as Deutsche Bank and Commerzbank, according to Moody’s (2007). These

two banks are also the first German banks that announced massive problems and had to be 
rescued in the wake of the financial crisis. IKB was rescued in July 2007 by substantial interventions of its owners.

Sachsen LB was the first Landesbank to be directly affected by the financial crisis. It was rescued in August 2007 and finally sold to Landesbank Baden-Württemberg so that it ceased to exist as a separate entity after April 2008. ${ }^{4}$ As shown in Table 1, Sachsen LB was owned by SFG (Sachsen-Finanzgruppe or Saxony Financial Group), which also directly owns eight savings banks in Saxony. Sachsen LB also acted as the wholesale bank for the savings banks in Saxony, and Moody's (2006) argues that the savings banks in Saxony and Sachsen LB were interdependent and closely linked to each other. ${ }^{5}$ Thus, the savings banks in Saxony were also directly affected by Sachsen LB's massive exposure and its subsequent risk of bankruptcy. As a consequence, the minister president of Saxony accepted the political responsibility for the losses at Sachsen LB and resigned, reflecting the political nature of the decision processes in Landesbanken.

Several other and substantially larger Landesbanken were exposed to risky assets in the summer of 2007 as well, albeit to a lower level. Moody’s (2007) thus concludes in September 2007 that "much of our concern and analysis has focused on German Landesbanks” (p.6), as the substantial exposure in combination with “weak profitability and only adequate levels of capitalization” would leave "some Landesbanks potentially vulnerable." The next two Landesbanken that had to announce massive losses were West LB (with total assets of €285 billion) in November 2007 and Bayern LB (with total assets of €353 billion) in February 2008. Both banks state in their quarterly and annual reports that these losses stem directly from their investments in the US subprime market. While West LB reported increased profitability and a positive earnings outlook in its report for the second quarter of 2007, it stated for the third quarter of 2007 that the previous outlook was not valid anymore as the subprime crisis had already resulted in write-downs of

\footnotetext{
4 The owners of Sachsen LB had to give a guarantee of $€ 2.75$ billion to Landesbank Baden-Württemberg (LBBW) to convince LBBW to buy Sachsen LB. This is the first-loss guarantee, i.e., the owners of Sachsen LB would have to bear losses of up to $€ 2.75$ billion before LBBW would step in for higher losses. Given that the Sachsen LB owners continue to be at risk, we treat the savings banks in Saxony as affected banks for the full period between August 2007 and June 2008.

5 Moody's (2006) argues: “In preparation for the abolition of support mechanisms in 2005, a strong liquidity compensation procedure was set up within the SFG group, whereby the SFG savings banks provide Sachsen LB with a binding liquidity line of more than $€ 5$ billion on a contractual basis” (p.5).
} 
$€ 355$ million. Similarly, Bayern LB recorded an operating profit of $€ 1$ billion for 2007, which was more than offset by subprime losses of $€ 1.9$ billion. Both banks were heavily criticized for revealing this information at a very late stage. In fact, parliamentary control groups later showed that these Landesbanken and their owners knew about their massive subprime losses in the third quarter of 2007 once the US subprime crisis hit. This is when the owners (savings banks) are likely to have first seen potential consequences of these losses. ${ }^{6}$

Landesbank Baden-Württemberg (LBBW) and HSH Nordbank were the final two Landesbanken that publicly announced losses from the US subprime market. However, the news came in November 2008 and thus after the end of the sample period. While both banks recorded profits for the first half of 2008 and gave a positive outlook for the remainder of the year, they publicly acknowledged losses after the Lehman Brothers bankruptcy and officially asked for government help in November 2008. Subsequently, we discuss how the timing of these banks' losses affects our analysis. $^{7}$

West LB announced the creation of a bad bank with assets worth €23 billion on February 2, 2008, along with guarantees worth $€ 5$ billion by the owners. The first losses of up to $€ 2$ billion are to be carried by all shareholders according to their ownership stakes, including the savings banks in North Rhine-Westphalia. In particular, as shown in Table 1, the two savings banks associations in North Rhine-Westphalia (Rheinischer Sparkassen- und Giroverband and Westfälisch-Lippischer Sparkassen- und Giroverband) hold more than 50\% of West LB. Similarly, Bayern LB announced on February 13, 2008 that it would have to write off about $€ 1.9$ billion due to the subprime crisis. As a consequence, the Bavarian savings banks decided on April 24, 2008, with a value-weighted majority of $96.9 \%$, to issue a guarantee worth $€ 2.4$ billion for the portfolio of asset-backed securities of Bayern LB. Similar to Sachsen LB, the losses in Bayern LB had political consequences. The former chairman of the supervisory board, who was also the Bavarian finance minister until 2007, accepted the responsibility and even apologized to the public and to the employees for not being able to avoid the disastrous losses. Thus, the savings banks in North Rhine-Westphalia and Bavaria were immediately affected by the losses

\footnotetext{
${ }^{6}$ See http://www.gruene-fraktion-bayern.de/cms/dokumente/dokbin/237/237520.schadensliste_bayernlb.pdf.

${ }^{7}$ As of September 2009, no other Landesbank is known to have asked for support from the German banking rescue package.
} 
resulting from the subprime exposure of their respective Landesbanken and had to provide vertical support. The resulting key question for the subsequent analysis is whether and to what extent the affected savings banks react in their lending policies to these losses.

To shed some light on this question, Fig. 1 presents aggregate lending data for savings banks as well as for the other banks in Germany, which are provided by the Deutsche Bundesbank, for the period between the beginning of 2006 and the end of the second quarter of 2008. Panel A shows lending figures for all three pillars of the German banking system (savings banks, cooperatives, and private banks), and it shows that total lending keeps increasing even after the beginning of the financial crisis in 2007. The same holds for total lending and corporate lending by the savings banks, as shown in Panel B of Fig. 1. Both lines show a clear and consistent upward trend even after August 2007. In contrast, retail lending by savings banks decreases over the same time period. This raises the question of whether the decline is due to retail customers asking for a lower amount of loans or to savings banks and affected savings banks rejecting more loan applications.

\section{INSERT FIGURE 1 HERE}

We address this question by analyzing individual loan applications in the sample period between July 2006 and June 2008. Until the end of the sample period, Sachsen LB, West LB, and Bayern LB were the only Landesbanken that showed losses from the subprime crisis. Fig. 2 illustrates the geographical location and reach of these three Landesbanken and shows that these banks operate in different regions in Germany. These regions are also heterogeneous in terms of their economic development as measured by GDP per capita, unemployment rate, and industry structure. While Saxony, which is the home of Sachsen LB and a former part of the German Democratic Republic, is among the least wealthy German states, Bavaria, where Bayern LB is headquartered, is among the wealthiest German states. North Rhine-Westphalia, which is the domicile of West LB and the most populous German state, ranges in the middle. During the rest of this paper, we exploit the exogenous variation as to which German savings banks are affected by the subprime mortgage crisis that started in the US and analyze whether affected banks behave differently from nonaffected banks. 


\section{INSERT FIGURE 2 HERE}

\section{Empirical strategy}

We analyze whether credit supply and demand is affected by the financial crisis. In particular, we employ a difference-in-differences (DID) approach to analyze the following two questions. First, does banks' supply of credit change when these banks are affected by the financial crisis, i.e., do they accept fewer loan applications? Second, does customers' demand for credit change in banks that are affected by the financial crisis, i.e., do customers apply less for loans or do they request lower loan amounts? We address these two questions by exploiting the specific setting in Germany, where savings banks represent a homogenous group of banks that operate according to a model of narrow banking throughout the country and are the owners of their respective regional Landesbanken. The identification for the empirical test is based on the fact that some but not all of the Landesbanken and thus some but not all of the savings banks are affected by the financial crisis.

The Landesbanken in Saxony, North Rhine-Westphalia, and Bavaria are the only Landesbanken that publicly announced losses from the US subprime crisis until the end of our sample period in June 2008. The savings banks in these regions are thus affected as well due to their respective ownership. There are two ways in which the exact event date for these savings banks can be defined. First, it can be defined based on the first public announcement of losses by their respective Landesbanken, which is the third quarter of 2007 for Sachsen LB, the fourth quarter of 2007 for West LB, and the first quarter of 2008 for Bayern LB. Second, it can be defined based on the first private announcement of losses by their respective Landesbanken, as, for example, in supervisory board meetings, which are attended by savings banks representatives. As the previously described results of the parliamentary control groups show, Landesbanken and their owners knew about the losses from the US subprime crisis up to six months before the public announcement of these losses. The event date based on this criterion is thus the third quarter of 2007 for all three Landesbanken. For the main empirical specification in this paper, we 
follow the second event definition, based on privately available information. In Section 6 we show the results from the first event definition, based on publicly available information.

All the remaining Landesbanken do not show losses from the US subprime crisis during the sample period. The savings banks in these regions are thus treated as nonaffected banks in the empirical specification. This also includes the owning savings banks of LBBW and HSH Nordbank as they show their first losses only in November 2008. However, to check the robustness of our results, we include these savings banks as affected banks for the latter part of the sample period (or alternatively leave them out) and rerun our empirical specifications. The results, which are discussed in Section 6, do not change.

We thus use two sources of identifying variation: the time before and after the financial crisis as well as the cross section of savings banks affected and not affected by the crisis based on the privately available information on the subprime losses that their Landesbanken have incurred. We estimate the following regression:

$$
\begin{aligned}
Y_{i, b, t}= & A_{b}+B_{t}+\delta^{*} X_{i, b, t}+\left(\beta_{1} * \text { Affected } * \text { Post-August } 2007\right) \\
& +\left(\beta_{2} * \text { Nonaffected } * \text { Post-August } 2007\right)+\varepsilon_{i, b, t \cdot}
\end{aligned}
$$

$Y_{i, b, t}$ takes a value of one if a loan application by customer $\mathrm{i}$ at bank $\mathrm{b}$ at time $\mathrm{t}$ is successful and zero otherwise. $A$ and $B$ are fixed effects for banks and time, respectively, and $X_{i, b, t}$ are individual controls that capture each borrower's risk as measured by the internal scoring. Affected is a dummy variable that takes a value of one if a savings bank is an owner of a Landesbank that is affected by the financial crisis, and Nonaffected is a dummy variable that takes a value of one if a savings bank is an owner of a Landesbank that is not affected by the financial crisis. PostAugust2007 is a dummy variable that takes a value of one if the loan application is made after August 2007, i.e., after the bailout of Sachsen LB and thus the beginning of the financial crisis, and zero otherwise. Finally, $\varepsilon_{\mathrm{i}, \mathrm{b}, \mathrm{t}}$ is an error term. The key variables of interest are the interaction terms Affected * Post-August2007 and Nonaffected * Post-August2007. We are interested in the difference between these two variables to see whether loan acceptance rates differ after the beginning of the financial crisis between savings banks that are affected by the crisis relative to 
those that are not affected. Our inference is thus based on a comparison of the coefficients $\beta_{1}$ and $\beta_{2}{ }^{8}$

\section{Data description and summary statistics}

We describe next in detail the data sources for our analyses and provide summary statistics.

\subsection{Data sources}

We obtain demand and supply data for the universe of consumer and mortgage loans by savings banks in Germany. These data are provided by S-Rating, which is the rating subsidiary of the German Savings Banks Association (DSGV), and present a unique opportunity to explore changes in demand and supply in consumer lending after the start of the financial crisis. These data span the time period between July 2006 (Q3-2006) and June 2008 (Q2-2008) and thus are equally made up of subperiods before and after the beginning of the financial crisis in August 2007.

We use only completed loan applications, so for each application we have an "accept" or "reject" decision. The final data set has 1,296,726 consumer and mortgage loan applications made by $1,117,175$ borrowers to 357 different banks. We have information about the internal rating of the borrower for 1,244,441 observations. For the subsample of mortgage loans, which has 317,616 observations, we also have information on the loan amount requested by the borrower.

There are five major advantages of this data set for the purpose of our study. First, it contains information on borrowers' loan applications as well as the banks' decisions for each individual loan application. This is a considerable advantage over, for example, Loan Pricing Corporation's Dealscan Database, which reports only the terms of actual loans. The combination of loan applications and loans granted enable us to clearly separate out the demand and supply effects in bank lending. Second, the loan decisions for retail borrowers constitute a separate approval

\footnotetext{
${ }^{8}$ Alternatively, one could rewrite the interaction terms as $\beta_{1} *$ Affected $+\beta_{2} *$ Post-August $2007+\beta_{3} *$ Affected $*$ PostAugust2007, which is the familiar difference-in-difference estimator (see, e.g., Gruber and Poterba, 1994).
} 
process by the bank and are provided as a lump sum. Unlike loans to corporate borrowers, they are thus not drawn down in fluctuating amounts over time. Third, we are able to obtain data on the bulk of the universe of savings banks in Germany, which use S-Rating's internal rating system in their lending decision process and transfer loan and borrower data back to S-Rating. This is thus a comprehensive data set, as the savings banks' market share in retail lending amounts to more than $40 \%$ in Germany, one of the world's largest bank-based financial systems. Fourth, the internal rating system meets the regulatory (Basel II) requirements ensuring the quality of the data used in this study. Fifth and finally, the large number of loan applications in the sample and the detailed information on each of these applications provides a unique opportunity to examine the differential treatment of new versus relationship customers.

\subsection{Loan and borrower characteristics}

Table 2 presents descriptive statistics for the loans and loan applicants in our sample. Of the total of 1,296,726 loan applications, 49.3\% are made in the period after August 2007. Of the loan applications, $36.5 \%$ are made to banks that are affected by the crisis, and the major portion of our data is consumer loan applications (71.5\%). Of all applications, $18.0 \%$ are made to the affected banks after August 2007, while 31.3\% are made to the nonaffected banks. On average, 95.6\% of all applications are accepted, and the average loan amount from the mortgage loan subsample amounts to 86,609 euros. On average, there are 40 loan applications to each bank per week.

\section{INSERT TABLE 2 HERE}

The primary measure of borrower credit risk in this study is the borrower's internal rating. This is based on a quantitative score, which uses a scorecard at the loan application stage to facilitate and standardize the credit decision process across all savings banks. This credit score adds up individual scores based on age, occupation (for example, nature of an applicant's job and years the applicant has been in the job), and monthly repayment capacity based on the borrower's available income. The score also contains information on the existence and use of the borrower's credit lines, as well as assets held in the bank. Based on past defaults of borrowers with similar characteristics, this score is consolidated into an internal credit rating, which is associated with a default probability of the borrower. Instead of using the individual borrower characteristics, we 
use the internal rating as it captures not only these characteristics but also additional private information of the banks as to past defaults of comparable borrowers. There are consistent rating bins for the internal ratings from April 1, 2007. Prior to this date we have the rating score, which we map into the same bins to ensure comparability over time.

The internal rating ranges from 1 to 12 , with 1 being associated with the lowest default probability. The average rating in our sample is 6 . Furthermore, $94.1 \%$ of the loan applications are made by relationship customers. An applicant has a relationship with the bank if he has a checking account with the bank prior to the loan application. ${ }^{9}$

Table 3 presents aggregate acceptance rates for affected versus nonaffected banks over time. Between the third quarter of 2006 and the second quarter of 2007, acceptance rates of both types of banks are similar, ranging from $97.2 \%$ to $98.3 \%$. Starting in the third quarter of 2007 , acceptance rates significantly drop within the group of affected banks. In particular, they drop from $97.6 \%$ in the second quarter of 2007 to $84.9 \%$ in the second quarter of 2008, but they remain unchanged among the nonaffected banks. The apparent similarity in acceptance rates between affected and nonaffected banks before the beginning of the financial crisis and the apparent difference between these two groups afterward provide further motivation for the difference-in-differences approach, which forms the main empirical testing methodology in this paper.

\section{Empirical results}

This section describes the main empirical analyses for loan demand and supply at affected and nonaffected banks and the impact of bank-borrower relationships.

\subsection{Loan acceptance rates after the beginning of the financial crisis}

We start analyzing the question of whether demand or supply effects are important in explaining the reduction in consumer loans after August 2007 by examining changes in acceptance rates of

\footnotetext{
${ }^{9}$ The regional principle excludes the possibility that a borrower has relationships with multiple sample banks.
} 
loan applications at the onset of the financial crisis. We use a difference-in-differences framework to identify a differential effect on affected versus nonaffected banks. The key identifying assumption is that trends related to loan acceptance rates are the same among affected and nonaffected banks in the absence of the financial crisis and are, therefore, perfectly captured by the class of nonaffected banks. This assumption obtains casual justification based on the parallel trend of acceptance rates as observed in Table 3.

\subsubsection{Bivariate results}

Table 4 presents bivariate results of the mean DID estimates of loan acceptance rates for affected and nonaffected banks. We report the mean acceptance rates for these two groups as well as the difference within each group before and after August 2007 and also the difference between the groups. Panel A reports the results for the pooled sample of consumer and mortgage loans, Panel B presents the results for consumer loans, and Panel C shows the results for mortgage loans. Standard errors are reported in parentheses, and the number of observations is reported in brackets. The DID estimate is in bold.

The acceptance rates of both types of banks before the start of the financial crisis in August 2007 are shown in the first row. While the difference between the two groups is 0.2 percentage points on average and statistically significant at the $1 \%$ level, the mean acceptance rate is $97.6 \%$ and of similar economic magnitude in the pooled sample as well as in the subsamples of mortgage and consumer loans. These results are consistent with Table 3.

Column 1 indicates that overall acceptance rates decrease on average by $4.1 \%$ after the start of the financial crisis. Most important for the purpose of our study, we find for the within-group variation in lending that nonaffected banks decrease their overall acceptance rates by $0.1 \%$, which is statistically only weakly significant and economically almost negligible. In contrast, affected banks substantially decrease their lending activity by $11.1 \%$ on average, which is significant at the $1 \%$ level. As a result, the DID estimates suggest affected banks reduce lending by $11 \%$, relative to nonaffected banks, which can be interpreted as the effect of the financial crisis on the supply of loans. We observe the same level of magnitude for the DID estimates of consumer and mortgage loans. 
In Panel D of Table 4, we present mean DID estimates for the pooled sample as a function of the borrowers' internal rating. We report the acceptance rates for each rating class and for affected and nonaffected banks both before and after August 2007 as well as three differences. The first difference is calculated for the comparison of acceptance rates of affected and nonaffected banks before August 2007. The figures show that the differences in acceptance rates between both groups and across the different rating classes are negligible. The second difference applies to the comparison of affected and nonaffected banks after August 2007. The differences in acceptance rates range from $8.5 \%$ to $18.9 \%$ and are highly statistically significant across all rating classes. The differences are highest for the two worst rating classes. They amount to $18.9 \%$ for rating class 11 and $16.0 \%$ for rating class 12 . These results for the comparison of acceptance rates by rating class are consistent with a slight migration to quality by affected banks, which tend to concentrate less on customers with the worst credit ratings. As a consequence, the third difference, which is presented in the last column and shows the DID estimates, is a continuous increase for the worst rating classes. While the DID estimates range about $10 \%$ for rating classes 1 to 8, they start increasing with rating class 9 and amount to $15.7 \%$ for rating class 11 and $15.0 \%$ for rating class 12 . Overall, the DID estimates indicate a robust result: Affected banks statistically and economically significantly reduce lending relative to nonaffected banks after August 2007 across all rating classes and tend to reduce it most for the worst rating classes. We further analyze and interpret the underlying reasons for this consistent decline across rating classes in our discussion of Table 6 in Subsection 5.1.2, where we more formally examine the overall distribution of borrower risk at affected banks before and after the crisis hit.

\subsubsection{Multivariate results}

To further control for the possibility that the differences in acceptance rates reported in Table 3 are due to changes in the characteristics of the affected or nonaffected banks over time, we further estimate linear probability models as shown in Eq. (1) for loan acceptance rates that control for these characteristics. ${ }^{10}$ Our main control variable is the applicant's internal rating at the time she applies for the loan. We further include bank-specific and time fixed effects. In

\footnotetext{
${ }^{10}$ Even if there are no relative changes in group characteristics between owners and nonowners, using covariates in regression DID can reduce the sampling variance of the DID estimator (Gruber and Poterba, 1994).
} 
some specifications, we also include a consumer confidence index that captures general trends in the economy.

Table 5 reports fixed effect linear probability models (LPM) of loan acceptance rates. ${ }^{11}$ We choose a linear model despite the binary nature of our dependent variable, which should favor nonlinear (probit or logit) models. The reason is that nonlinear models suffer from an incidental parameters problem, i.e., the fixed effects and, more important, the coefficients of the other control variables cannot be consistently estimated in large but narrow panels (with T fixed and $N$, the number of groups, growing infinitely). ${ }^{12}$ Linear models, however, can consistently estimate the coefficients of our main explanatory variables and therefore provide an economically meaningful measure for the link between the financial crisis and the lending behavior of banks in our setting. Our results are robust to probit as alternative estimation method. We provide a more detailed discussion and comparison of the linear probability model and the probit model (with and without fixed effects) in Section 5.

\section{INSERT TABLE 5 HERE}

Panel A reports regression results for the pooled sample of consumer and mortgage loans, and Panels B and C report separately the results for the consumer and mortgage loan subsample. Heteroskedasticity consistent standard errors are shown in parentheses. The estimation controls for bank and year fixed effects, which, in addition to the intercept, are not shown. Models 3, 6, and 9 further adjust the standard errors for possible autocorrelation at the bank level. The key variable of interest is presented in the diagnostic section of Panel A of Table 5, which reports the DID estimate as well as the $p$-value from the Wald test under the null hypothesis that the DID estimate is equal to zero.

\footnotetext{
${ }^{11}$ The LPM is measured by ordinary least squares (OLS). We do not use weighted least squares (WLS) even though the weights (the conditional variance function) can be easily estimated from the underlying regression function. However, if this estimate is not very good, the WLS have worse finite sample properties than OLS and inferences based on asymptotic theory might be misleading (Altonji and Segal, 1996).

${ }^{12}$ The inconsistency of the incidental parameters (fixed effects) arises because the number of incidental parameters $\mathrm{N}$ increases without bounds while the amount of information about each parameter is fixed (Neyman and Scott, 1948). The coefficients of the other control variables are generally also inconsistent (Andersen, 1973 and Wooldridge, 2002).
} 
The coefficients on the control variables are as expected, i.e., higher quality applicants are more likely to get loans. More important for the purpose of our study, our results confirm the conclusions from Table 4. Even after controlling for other factors and each borrower's internal rating, we find that affected banks significantly reduce acceptance rates of loans after August 2007 while nonaffected group banks even increase consumer lending by $1.1 \%$. The significance of the latter result vanishes though once we allow for autocorrelation at the bank level. The DID estimate of $8.2 \%$ is highly significant in any specification and corresponds to $73 \%$ of the effect estimated in Table 4. The economic magnitude of this result is large. A decrease in consumer lending by $8.2 \%$ is equivalent to saying that rejection rates almost double for affected banks.

Panel B of Table 5 reports the regression DID results for the subsample of consumer and mortgage loans. The results are similar to the results from the full sample. The DID estimate is 7.3\% for consumer loans and $12.2 \%$ for mortgages. The LPM results are in line with the bivariate DID estimates in Table 4 and suggest that affected banks respond to the financial crisis significantly restricting the access to loans. The diagnostic section of Panel B further reports the $p$-value from the Wald test under the null hypothesis that, within the group of affected banks, loan applicants for mortgage loans are as likely to be accepted as applicants for consumer loans after the start of the financial crisis. We can reject this hypothesis at any confidence level. This result is intuitively plausible, as mortgage loans represent a more significant commitment of the bank vis-à-vis their borrowers as compared with consumer loans. In other words, if the affected banks are concerned with being forced to inject considerable equity into their Landesbanken and curtail lending accordingly, the likelihood of being rejected should be positively related to the commitment the banks make by extending the loan. And the difference in the reduction in acceptance rates is sizable between both types of loans with the reduction being almost twice as large for mortgage loans. Taken together, our results suggest that banks constrain lending as a result of the financial crisis.

An important question is which of the affected banks curtail lending the most. To investigate this, we exploit the heterogeneity among the 146 affected savings banks in our sample. We observe these banks in the time period after August 2007 and analyze in a cross-sectional regression as to how bank-specific characteristics affect their lending decisions. As we are 
interested in the effect of bank characteristics such as size and liquidity, which are recorded only on a yearly basis for our sample banks, we cannot use bank fixed effects in this empirical specification as the fixed effects would absorb our variables of interest. To account for possible autocorrelation at the bank level, we cluster standard errors accordingly. ${ }^{13}$ Bank size is the natural logarithm of total assets measured in millions of euros. Liquidity is the ratio of the bank's cash and marketable securities to its total assets.

The results for the cross-sectional regressions are reported in Table 6. We report the results for both bank size and liquidity for the pooled sample (Models 1 and 4) as well for the subsamples of consumer loans (Models 2 and 5) and mortgage loans (Models 3 and 6). Model 1 shows that larger affected banks are more likely to accept loan applications after the onset of the financial crisis compared with smaller affected banks. The coefficient for bank size is significant at the $1 \%$ level. These results suggest that smaller banks are hit much more severely by the financial crisis and their resulting obligation to help their respective Landesbank than larger banks. Mortgage loans represent a more significant commitment of banks vis-à-vis their borrowers. Consequently, we expect the effect of bank size to be more pronounced in the subsample of mortgage loans. We repeat the regression specification used in Model 1 in subsamples of consumer and mortgage loans and find empirical support for our hypothesis. The effect of bank size is almost twice as high for mortgage compared with consumer loans. One possible explanation for this result is that smaller banks do not have sufficient liquidity left after injecting additional capital into their Landesbanken. In fact, the correlation of bank size and liquidity before the crisis amounts to 0.56 and is significant at the $1 \%$ level. In Models 4 to 6 , we test this relation more formally and find that banks with higher liquidity ratios show substantially larger acceptance rates than banks with lower liquidity ratios. Banks with low level of liquidity substantially reduce their customer lending. ${ }^{14}$ We test this separately for consumer and mortgage loans and find that this effect almost triples for mortgage loans, which is again consistent with mortgage loans constituting a larger commitment compared with consumer loans.

\footnotetext{
${ }^{13}$ We also use a diff-in-diff-in-diff specification with bank size and liquidity as a third type of identifying variation apart from the time before and after August and the difference between affected and nonaffected banks. The results do not change.

${ }^{14}$ See also Jiménez, Ongena, Peydró, and Saurina (2010) for the effect of liquidity on credit supply in Spain.
} 


\section{INSERT TABLE 6 HERE}

Do affected banks reduce their lending to preserve liquidity or to reduce portfolio risk? Our analysis help throw some light on this question. Panel D of Table 4 suggests that affected savings banks reduce lending relative to nonaffected savings banks across all rating classes, with a slight migration to quality. Even for the highest quality customers, we find an economically sizable effect of 9 to 10 percentage points. It is worth asking if the overall risk distribution of loans made is significantly different for affected versus nonaffected banks. Given our large sample size and given the fact that the chi-square coefficient is sensitive to it, we use a variant of the chi-square test that controls for the sample size effect to test for this. We employ Cramer's V as the most commonly used measure, which is bounded between zero and one with zero showing no and one showing perfect association (See Cramer, 1999). We find that the risk distribution of accepted loans before or after August 2007 is not different for affected banks or nonaffected banks (Cramer's V of 0.023 and 0.032, respectively). Similarly, the comparison of the risk distribution of accepted loans between affected and nonaffected banks shows no difference before or after August 2007 (Cramer's V of 0.048 and 0.042, respectively). Thus, the overall distribution does not change despite the slight migration to quality as observed in Table 4.

Our results in Table 6 further speak to the question of whether the affected banks reduce lending to preserve liquidity or to reduce portfolio risk. Table 6 suggests that small banks and banks with low levels of liquidity are more likely to reject loan applications among the affected savings banks. We investigate this further by analyzing the distribution of ex ante borrower quality among small and large affected banks using a chi-square test. If the banks' primary concern is to reduce risk, we expect to find a significant change in the risk distribution of loans made before and after August 2007 for small versus large banks. We do not find evidence for an association of ex ante borrower quality and whether or not the affected bank is small or large. Cramer's V, our measure of association, is 0.0287 before August 2007 and 0.0319 after August 2007. This suggests that there is no change in ex ante borrower quality for small versus large banks.

Taken together, our results indicate that the banks hit hardest on liquidity reduced lending more but did not change the risk distribution of loans. Our results suggest that preserving liquidity 
instead of reducing portfolio risk seems to be the primary reason that affected savings banks reduce lending after August 2007.

\subsection{The demand for loans after the beginning of the financial crisis}

The main objective in this paper is to separate supply and demand effects of the financial crisis on consumer lending. So far we have analyzed the supply effects, and we now turn to examine whether the demand for loans from borrowers has changed as a consequence of the financial crisis. We focus on two possible ways in which loan demand could be affected. First, there could be a general decline in demand throughout Germany. Second, customers from affected savings banks could reduce demand more relative to customers from nonaffected banks. This can be tested within the same framework we use to analyze supply effects in lending. The coefficients $\beta_{1}$ and $\beta_{2}$ from Eq. (1) show the general trend, and the difference between both coefficients is an estimate as to how consumer demand is affected. The dependent variable is a proxy for loan demand. In Subsection 5.2.1., we use the number of loan applications per week as the dependent variable. In Subsection 5.2.2., we use the natural logarithm of the loan amount requested by the borrower as a proxy for loan demand.

\subsubsection{The number of loans requested by applicants}

Table 7 reports the regression results for the number of loans requested by borrowers each week. We report the regression results for the pooled sample of consumer and mortgage loans in Columns 1 and 2, the results for consumer loans in Columns 3 and 4, and the results for mortgage loans in Columns 5 and 6. The regressions are estimated using a fixed effect OLS model and a negative binomial model (NBM) with fixed effects to account for the count data nature of the dependent variable. We further adjust the standard errors for possible autocorrelation at the state level. The diagnostic section of the table reports the DID estimate as well as the $p$-value from the Wald test under the null hypothesis that the DID estimate is equal to zero. The unit of our analysis is the number of weekly loan applications to each single bank and not an individual loan application. This reduces our sample size compared with Table 4 and Table 5. Accordingly, to control for borrower risk, we use the mean internal rating, which is the average of the internal rating score across all loan applications per bank in a given week. When using the negative binomial model, we further report the likelihood ratio test and in each case 
reject the null hypothesis that conditional mean and median of the number of weekly loan applications are identical. The statistically significant evidence of overdispersion indicates that the negative binomial model is preferred to the Poisson regression model. We further do not find an elevated number of zeros in the dependent variable and therefore do not report the regressions using either Poisson or the zero-inflated Poisson model. Intercept, bank, and time fixed effects are not shown. Heteroskedasticity consistent standard errors are shown in parentheses.

\section{INSERT TABLE 7 HERE}

The regression results indicate a decline in the number of loan applications for both affected and nonaffected banks by 8.1 and 9.7 loans per week, respectively. To assess the economic magnitude of the result, we evaluate this number at the average number of loan applications, which amounts to 40 . In other words, the change in the number of loan applications is approximately $20 \%$ to $25 \%$ of the average number of weekly loan applications during our sample period, and it is statistically significant at the $1 \%$ level in almost all specifications. The results of the negative binomial model are consistent with this interpretation. The DID estimates, however, are insignificant in all tests. Taken together, borrowers' loan demand decreases after August 2007, but it does not decrease significantly more at banks that are affected by the financial crisis. The overall decrease in borrower demand despite the stable economic environment in Germany during the sample period suggests that customers anticipate a deterioration of the economic climate and adjust their borrowing behavior accordingly.

\subsubsection{The amount of loans requested by applicants}

We next examine whether customers, given that they apply for a loan, request lower loan amounts. We therefore use the natural logarithm of the loan amount requested by the borrower as proxy for loan demand. Loan amounts are available for the subset of 317,583 mortgage loans in our sample. Our main control variable is the applicant's internal rating at the time she applies for the loan. We further include bank-specific and time fixed effects. In some specifications, we also include a consumer confidence index, which captures general trends in the economy. 
Table 8 reports the results using a fixed effect OLS model. Column 3 further adjusts the standard errors for possible autocorrelation at the state level. The diagnostic section of the table reports the DID estimate as well as the $p$-value from the Wald test under the null hypothesis that the DID estimate is equal to zero. Intercept, bank, and year fixed effects are not shown. Heteroskedasticity consistent standard errors are shown in parentheses. Among affected and nonaffected banks, loan amounts decline by 4.9\% and 4.5\%, respectively, after August 2007. This result suggests that there is an overall decline in loan demand in Germany that is significant at the $1 \%$ level. The significance, however, dissipates if we allow for autocorrelation at the state level. Furthermore, the DID estimate in the diagnostic section is 0.0046, which is insignificant in all tests. Overall, the results indicate that there is not much evidence for a decrease in loan amounts after August 2007 and thus for a causal effect of the financial crisis on the loan amount requested by applicants at least until June 2008.

\section{INSERT TABLE 8 HERE}

\subsection{Bank-borrower relationships after the beginning of the financial crisis}

A natural question relates to the role of relationships in credit rationing. Our results so far suggest that customers of affected banks are more likely to have their loan applications rejected. Do customers with bank relationships benefit from them and thus have a higher likelihood of being approved during a financial crisis? To answer this question, we test whether applications by existing customers of affected banks are more likely to be approved than by new customers at the same bank after the start of the financial crisis. A possible approach is to do a difference-indifferences test for acceptance rates of relationship versus nonrelationship customers before and after August 2007 within the group of affected banks. However, changes in acceptance rates of relationship versus nonrelationship applicants over time that are not caused by the financial crisis could cause a spurious correlation. A difference in acceptance rates between both groups would thus be falsely attributed to the crisis.

To avoid this problem, we use a difference-in-difference-in-difference framework, which is tested in the same way as in Gruber and Poterba (1994). In addition to the time before and after August 2007 as well as the cross section of savings banks that are affected or not affected by the 
crisis, we use the relationship status as the third source of identifying variation. In this framework, the change in acceptance rate by relationship status of nonaffected savings banks serves as a control for a general trend related to acceptance rates by relationship versus nonrelationship borrowers. The difference-in-difference-in-difference nets out any relationship effect on acceptance rates due to unobservables or quality variables (Ashenfelter and Craft, 1985).

$$
\begin{aligned}
Y_{i, b, t} & =A_{b}+B_{t}+\delta^{*} X_{i, b, t}+\left(\beta_{1} * \text { Post-August2007 }\right)+\left(\beta_{2} * \text { Relationships }\right) \\
& +\left(\beta_{3} * \text { Affected } * \text { Post-August2007 }\right)+\left(\beta_{4} * \text { Relationships } * \text { Post-August2007 }\right) \\
& +\left(\beta_{5} * \text { Affected } * \text { Relationships }\right)+\left(\beta_{6} * \text { Affected } * \text { Post }- \text { August2007 } * \text { Relationships }\right)+\varepsilon_{i, b, t, r}
\end{aligned}
$$

The variables Post-August2007 and Affected are defined in the same way as before. Relationships is a dummy variable that takes a value of one if an existing customer applies for a loan and zero otherwise. The key variable of interest is the triple interaction term Affected * Post-August2007 * Relationships. This variable thus measures whether existing customers receive better treatment than new customers after the beginning of the financial crisis when their bank is affected by the financial crisis; or, to put it in a different way, whether existing relationships to a bank are valuable in times of a financial crisis when this bank is affected by the crisis. Our inference is thus based on the coefficient $\beta_{6}$.

Table 9 reports the regression results. Similar to Table 5, we use a linear probability model with fixed effects and fit regression Eq. (2) to the pooled sample as well as the subsample of consumer and mortgage loans. Intercept, bank, and year fixed effects are not shown. Heteroskedasticity consistent standard errors are shown in parentheses. The results support our earlier findings. The coefficient $\beta_{3}$ (Affected * Post-August2007) corresponds to our earlier DID estimate in Table 5. The estimate is of similar magnitude indicating that customers of affected banks have an $8.1 \%$ lower probability of being approved than customers of nonaffected banks. The secular effect of relationships is positive and significant, indicating that bank-depositor relationships are valuable even in the absence of the financial crisis. Relationship customers are 2.8\% more likely to receive a loan compared with new customers. Most important for the purpose of this study, our results are consistent with relationship customers benefiting from 
lending relationships during the financial crisis. The coefficient of the variable Affected * PostAugust2007 * Relationships is positive and significant at the 1\% level. Holding everything else constant, applications by relationship customers are $4.9 \%$ more likely to be approved after August 2007 relative to new customers. This result holds also in the subsamples of consumer and mortgage loans. Relationship customers have a 4.1\% higher likelihood of being approved than new customers when they apply for a consumer loan and a 1.8\% higher likelihood of being approved when they apply for a mortgage loan.

\section{INSERT TABLE 9 HERE}

The diagnostic section of Table 8 further reports the Wald test under the null hypothesis that the treatment effect is identical in the subsample of consumer and mortgage loans. We reject the hypothesis and confirm the earlier evidence that mortgage loans are significantly less likely to be approved relative to consumer loans. While relationships are important and significant for both types of loans, the diagnostic section also shows that they are most important for consumer loans. This suggests that the information that a bank generates from a customer relationship is most important in approvals of loans that are not secured by collateral and hence the repayment and recovery rate probably depend on the borrower's creditworthiness than the value of the collateral. This result is consistent with the literature on small business lending. For example, Berger and Udell (1995) show that relationships are less relevant for mortgage loans relative to credit lines, which is the analogy to consumer loans in our setting.

\section{Robustness}

In this section, we provide several additional analyses to test the validity of the empirical specification and the robustness of the results.

\subsection{Linear probability model versus probit model}

In Table 5 and Table 9 we use the LPM to fit a regression with a binary dependent variable. This empirical testing strategy could be questioned as the LPM is heteroskedastic and it can predict 
values on the interval minus to plus infinity. For these two reasons, nonlinear models as for example probit models are commonly used to fit binary data. However, in a panel-data setting, the LPM has an important advantage over probit models. While the incidental parameters cannot be consistently estimated if $N \rightarrow \infty$ and $\mathrm{T}$ is fixed, the other explanatory variables are $\sqrt{ } N$ consistent (Wooldridge, 2002). In probit models, the explanatory variables are generally inconsistent. In this subsection, we fit a probit model with and without fixed effects to the data and compare the results. In Table 10, we estimate the probability that a bank accepts a loan application. Only the coefficients for the key explanatory variables are shown for the LPM. The reported coefficient in the probit models is the effect of a marginal change in the corresponding variable on the probability that a loan application is approved, computed at the sample mean of the independent variables. Heteroskedasticity consistent standard errors are shown in parentheses. Table 10 further reports the $p$-value of the Wald test under the null hypothesis that the DID estimate is zero.

\section{INSERT TABLE 10 HERE}

The LPM coefficients are taken from Model 2 in Table 5. The results confirm our previous finding. In particular, the magnitude of the coefficients in the probit model without fixed effects is generally similar to that in the LPM. Even though the DID estimate is about 2\% smaller in the mortgage loan sample using the probit model, the difference in the DID estimate between consumer and mortgage loans is still significant at the $1 \%$ level. The magnitude of the coefficients in the probit model with fixed effects is 50\% smaller compared with both alternative models. For example, the DID estimate in the pooled sample is $4 \%$ vis-à-vis $8 \%$ in the LPM. Most important, the overall result of this paper, i.e., banks reduce the supply of loans as a consequence of the financial crisis, is confirmed in all tests and the effect is still economically significant.

\subsection{Geographic proximity and access to credit}

We argue in Subsection 2.2 that the three affected Landesbanken operate in different geographic regions in Germany, which are also heterogeneous in their economic development. The results 
in this paper are thus unlikely to be determined by a common economic shock that only affects these regions but not any other region in Germany. Nonetheless, we conduct additional robustness checks. In particular, we follow the methodology in Huang (2008) and compare the lending behavior of geographically contiguous savings banks, which belong to different Landesbanken. We compare the lending behavior of a savings bank in a federal state with an affected Landesbank with that of a neighboring savings bank in a federal state without an affected Landesbank. As geographically contiguous savings banks face very similar economic conditions and only differ in their respective Landesbank ownership, this is a clean test to observe whether the change in lending behavior is due to the Landesbanken losses.

We thus repeat the empirical analysis from Table 5 for only those contiguous savings banks in which one is affected through its Landesbank and the other one is not. We have 31 groups of affected and not affected savings banks. The results are presented in Table 11 and are very similar to, and perhaps even stronger than, those in Table 5. The coefficient for the affected banks after August 2007 amounts to less than -0.14 and is highly significant in Model 1. We repeat the analysis in subsamples of consumer and mortgage loans and, again, the results are very similar. Model 4 confirms the results using a probit model as robustness check.

\section{INSERT TABLE 11 HERE}

\subsection{Definition of events and affected banks}

As argued in the description of the definition of the empirical strategy in Section 3, the reported results in the main tables are based on the event date August 2007 when the losses of the Landesbanken became privately observable to their owners and thus the savings banks, for example, in supervisory board meetings. The event date can be alternatively chosen by defining the day on which the losses become publicly observable. This is the case in the third quarter of 2007 for Sachsen LB, in the fourth quarter of 2007 for West LB, and in the first quarter of 2008 for Bayern LB. We thus rerun our empirical analyses with this alternative choice of event dates and report the results in Table 12. The results are very similar to those reported in Table 5 and show the same patterns as before. 


\section{INSERT TABLE 12 HERE}

As also argued in Section 3, the Landesbanken other than Sachsen LB, West LB, and Bayern LB do not show subprime losses during the sample period. The savings banks in these regions are thus treated as nonaffected banks in the main empirical analysis. While this definition is clear even at hindsight for most Landesbanken, it might be questioned for LBBW and HSH Nordbank. Both banks did not show losses during the sample period and publicly announced losses only in November 2008. Nonetheless, it could be argued that their earnings in the second quarter of 2008 were somewhat lower than those in the first quarter of 2008 so that insiders might have already foreseen their upcoming problems. We thus rerun our analyses by including LBBW and HSH Nordbank as affected banks for the second quarter of 2008. The results in Models 5 to 8 of Table 12 are again very similar to those of Table 5. An alternative robustness test would be to drop these two Landesbanken from the sample altogether. We do not report these tables to conserve space, but again we find the results are very similar.

\subsection{Parallel-trend assumption}

We further want to test whether the difference-in-differences tests are not driven by inappropriate identification assumptions. The key identifying assumption in our empirical strategy is that trends related to loan acceptance rates are the same among affected and nonaffected banks in the absence of the financial crisis. In Table 2, we observe a parallel trend in average loan acceptance rates between affected and nonaffected banks before August 2007, which is an indicator that this assumption is reasonable. In this subsection, we formally test the parallel-trend assumption using out-of-sample data. We implement a control experiment using a loan sample for the period January 2006 through December 2006 and define July 1, 2006 as the fictitious event. ${ }^{15}$ If the parallel-trend assumption holds, we should see no difference in acceptance rates before and after the event between the affected and nonaffected banks.

We obtain data for the out-of-sample period from S-Rating for the same loan types from the same banks with the same internal scoring mechanism. We then implement the difference-in-

\footnotetext{
${ }^{15}$ Control experiments or placebo events are commonly used in the literature to test the parallel-trend assumption (Duflo, 2001) or correct biases in the DID estimate (Huang, 2008).
} 
differences test around the fictitious event described in Section 3. We have information about 504,179 consumer and mortgage loans in this sample. The coefficients in Eq. (1) describe the trend in loan acceptance rates after July 2006 for affected versus nonaffected banks, and the difference is the DID estimate. Holding everything else constant, loan acceptance rates increase by $0.03 \%$ for the affected banks after the event $(p=0.919)$ and by $0.18 \%$ for nonaffected banks ( $p=0.379)$. The DID estimate is insignificant $(p=0.735)$, indicating no change in acceptance

rates for the affected banks relative to the nonaffected banks, which further supports the identifying assumption of our empirical strategy.

\subsection{Borrower quality and loan acceptance rates}

Finally, we want to make sure that our results are not driven by a change in ex ante borrower quality. If the distribution of borrower quality changes over time and for affected versus nonaffected banks, can this explain why affected banks reduce consumer lending more than nonaffected banks? This question has two aspects: a declining trend in borrower quality and a change in the risk distribution of the applicants of affected versus nonaffected banks. Our difference-in-differences approach controls for the first aspect. If there is a common trend in borrower quality, it is captured by the difference-in-differences approach and thus the control group of nonaffected banks. For the second aspect, we use a chi-square test to analyze whether the risk distribution is independent of consumers applying before or after August 2007 and with affected and nonaffected banks. We find evidence that no association exists between the risk distribution and whether the application is made before or after August 2007 for either affected banks (Cramer's V amounts to 0.029) or nonaffected banks (Cramer's V amounts to 0.026). There is thus no statistically significant trend in borrower quality over time. We further test whether there is a change in the risk distribution for affected versus nonaffected banks using the same test. We find that Cramer's V is 0.041 before August 2007 and 0.044 after August 2007. Thus, the risk distribution of applicants is independent of whether or not a bank is affected by the financial crisis both before and after August 2007, which implies that there is no change in borrower quality for affected versus nonaffected banks. Thus our results are not driven by a change in ex ante borrower quality. 


\section{Conclusion}

In this paper we take advantage of a unique data set to study the real effects of the financial crisis through the global supply of credit. We have the universe of loan applications and loan approvals for German savings banks in a time period that spans the financial crisis. We have a unique experimental setting in that some of our local savings banks, while they engage in narrow banking, are substantially affected by the US financial crisis through the Landesbanken that they own, which in turn have substantial exposure to subprime assets in the United States. We can compare their lending patterns with savings banks that do not have similar exposure. Using data from 2006-2008 (pre- and post-crisis) we are also able to distinguish between demand and supply effects of the financial crisis. While there is an overall decrease in demand of loan applications once the crisis strikes, we do not find significant differences in the loan applications for affected versus nonaffected banks.

We find evidence of a substantial supply effect in bank credit to retail customers. Using a difference-in-differences analysis we find that the affected savings banks reject more loan applications than the nonaffected banks. These results survive a large number of robustness checks. We also find that savings banks curtail their lending in particular when they are small and more liquidity-constrained. In addition, there is a bigger effect for mortgages as compared with consumer loans and a slight migration to quality. However, the distribution of ex ante borrower and portfolio risk for affected and nonaffected banks before and after the onset of the financial crisis is not statistically significantly different. Our evidence thus suggests that banks cut back on lending to preserve liquidity. Finally, we assess the effect of bank-depositor relationships and find that relationships help mitigate the supply side effect. Our findings illustrate the global linkages for the supply of credit and suggest a number of avenues for future research and policy makers. A key aspect is whether and to what extent the reduced supply of credit in some regions affects the real economy in these regions, e.g., through a reduction of consumer spending or a reduction in construction. Related to this, it is important to understand from a policy perspective how the supply of credit can be secured even if certain banks are affected by a financial crisis. 


\section{References}

Allen, F., Gale, D., 2000. Financial contagion. Journal of Political Economy 108, 1-33.

Altonji, J. G., Segal, L. M., 1996. Small-sample bias in GMM estimation of covariance structures. Journal of Business and Economic Statistics 14, 353-366.

Andersen, E. M., 1973. Conditional Inference and Models for Measuring. Mentalhygiejnisk Forsknings Institut, Copenhagen, Denmark.

Ashenfelter, O., Card, D., 1985. Using longitudinal structure of earnings to estimate the effect of training programs. Review of Economics and Statistics 67, 648-660.

Berger, A., Dai, Q., Ongena, S., Smith, D., 2003. To what extent will the banking industry be globalized? A study of bank nationality and reach in 20 European nations. Journal of Banking and Finance 27, 383-415.

Berger, A., Udell, G., 1995. Relationship lending and lines of credit in small firm finance. Journal of Business 68, 351-382.

Bernanke, B., 1983. Nonmonetary effects of the financial crisis in the propagation of the Great Depression. American Economic Review 73, 257-276.

Bernanke, B., Blinder, A., 1988. Credit, money, and aggregate demand. American Economic Review Papers and Proceedings 78, 435-439.

Bernanke, B., Blinder, A., 1992. The federal funds rate and the channels of monetary transmission. American Economic Review 82, 901-921.

Chari, V., Christiano, L., Kehoe, P., 2008. Facts and myths about the financial crisis of 2008. Unpublished working paper.

Cramer, H., 1999. Mathematical Methods of Statistics. Princeton University Press, Princeton, NJ.

Duchin, R., Ozbas, O., Sensoy, B., 2010. Costly external finance, corporate investment, and the subprime mortgage credit crisis. Journal of Financial Economics 97, 418-435.

Duflo, E., 2001. Schooling and labor market consequences of school construction in Indonesia: evidence from an unusual experiment. American Economic Review 91 (4), 795-813.

Fitch, 2007. Landesbanks revisited—progress is slow. Special report.

Gan, J., 2007. The real effects of asset market bubbles: loan- and firm-level evidence of a lending channel, Review of Financial Studies 20, 1941-1973. 
Gruber, J., Poterba, J., 1994. Tax incentives and the decision to purchase insurance: evidence from the self-employed. Quarterly Journal of Economics 109, 701-733.

Huang, R. R., 2008. Evaluating the real effect of bank branching deregulation: comparing contiguous counties across US state borders. Journal of Financial Economics 87, 678-705.

Ivashina, V., Scharfstein, D., 2010. Bank lending during the financial crisis of 2008. Journal of Financial Economics 97, 319-338.

Jimenéz, G., Ongena, S., Peydró, J., Saurina, J., 2010. Credit supply: identifying balance-sheet channels with loan applications and granted loans. CEPR working paper.

Kobayakawa, S., Nakamura, H., 2000. A theoretical analysis of narrow banking proposals. Monetary and Economic Studies 18, 105-118.

Krugman, P., Obstfeld, M., 2008. International Economics: Theory and Policy, 8th ed., Pearson International Edition.

Mian, A., 2006. Distance constraints: the limits of foreign lending in poor economies. Journal of Finance 61, 1465-1505.

Moody's, 2004a, Assessing Germany's public sector banks and their cross-sector support mechanisms. Bank credit strength assessment.

Moody's, 2004b, German public sector banks after July 2005: focus shifts to support, cooperation and solidarity within the sector. Special comment.

Moody’s, 2006. Analysis Landesbank Sachsen GZ. December.

Moody’s, 2007. German banking system: regional focus. Special comment.

Neyman, J., Scott, E. L., 1948. Consistent estimates based on partially consistent observations. Econometrica 16, 1-32.

OECD, 2008. Economic Outlook 84, annex table no. 59.

Peek, J., Rosengren, E. S., 1997. The international transmission of financial shocks: the case of Japan. American Economic Review 87, 495-505.

Petersen, M., Rajan, R., 1994. The benefits of lending relationships: evidence from small business data. Journal of Finance 49, 1367-1400.

Rajan, R., Zingales, L., 2003. The great reversals: the politics of financial development in the 20th century. Journal of Financial Economics 69, 5-50. 
Stiglitz, J., Weiss, A., 1981. Credit rationing in markets with imperfect information. American Economic Review 71, 393-410.

Wooldridge, J. M., 2002. Econometric Analysis of Cross Section and Panel Data. MIT Press, Cambridge, MA. 


\section{Appendix}

\section{Main variables definitions}

\author{
Variable \\ Inference variables \\ Affected \\ Post-August 2007 \\ Affected x Post-August 2007 \\ Nonaffected x Post-August 2007 \\ Loan type \\ Mortgage Loans \\ Dependent variable \\ Accepted (Yes/No) \\ Loan amount \\ No. of weekly loan applications \\ Control variable \\ Consumer Confidence
}

Borrower characteristics Internal Rating

Relationships characteristics Relationships

\section{Definition}

Dummy variable equal to one if the application is made to a savings bank that owns one of the affected Landesbanken (Bayern LB, Sachsen LB, West LB).

Dummy variable equal to one if the loan application is made after August 2007.

Interaction term: dummy variable equal to one if loan application is made to an affected savings bank after August 2007.

Interaction term: dummy variable equal to one if loan application is made to a nonaffected savings bank after August 2007.

Dummy variable equal to one if the loan type is a mortgage loan.

Dummy variable equal to one if the loan application was accepted. The loan amount requested by the borrower in euros. The loan amount is available only for the subset of mortgage loans.

Number of loan applications per bank per week.

Measured by the Konsumklimaindex (consumer climate index) of the market research company GfK and is based on a monthly survey of two thousand consumers of age 14 and above. The index contains questions about how much consumers expect the economy and their income to grow and what they plan to consume. One sample question is: "Do you think it is currently advisable to spend a lot of money for consumption?" Three answers are possible: advisable, neutral, and not advisable. The answers are transferred into numbers and aggregated for all parts. The index long-term average is about zero.

Based on a quantitative score that uses a scorecard at the loan application stage to facilitate and standardize the credit decision process across all savings banks. This credit score adds up individual scores based on age, occupation (for example, nature of an applicant's job and years the applicant has been in the job), and monthly repayment capacity based on the borrower's available income. The score also contains information on the existence and use of the borrower's checking and other accounts, i.e., credit or debit cards, the use of credit lines, and assets held in the bank. Based on past defaults of borrowers with similar characteristics, this score is consolidated into an internal credit rating, which is associated with a default probability for the borrower.

Dummy variable equal to one if the loan applicant had a checking account with the same bank before the application. The regional principle excludes the possibility that a borrower has relationships with multiple sample banks. 
Fig. 1. Aggregate lending in Germany.

The figure shows the aggregate lending of German banks for the January 2006 to June 2008 period. Panel A shows the aggregate lending (corporate and consumers) for all bank groups. Panel B shows the aggregate consumer and corporate lending for savings banks. Loan types do not include mortgage loans. Source is Deutsche Bundesbank.

Panel A: Total lending

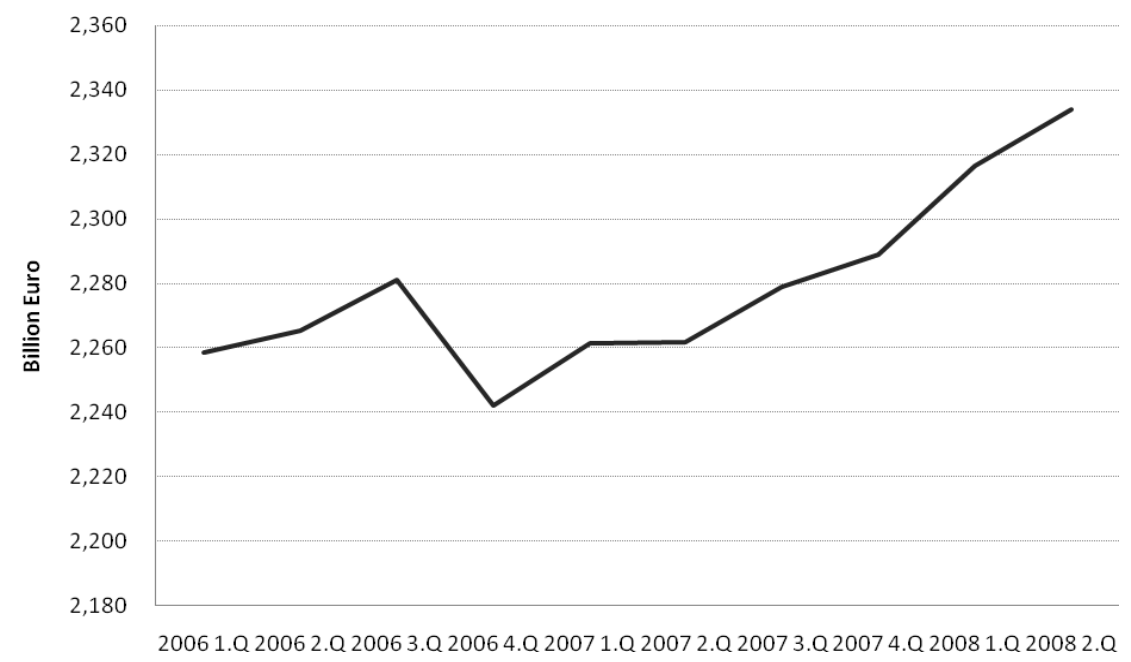

Panel B: Lending by savings banks

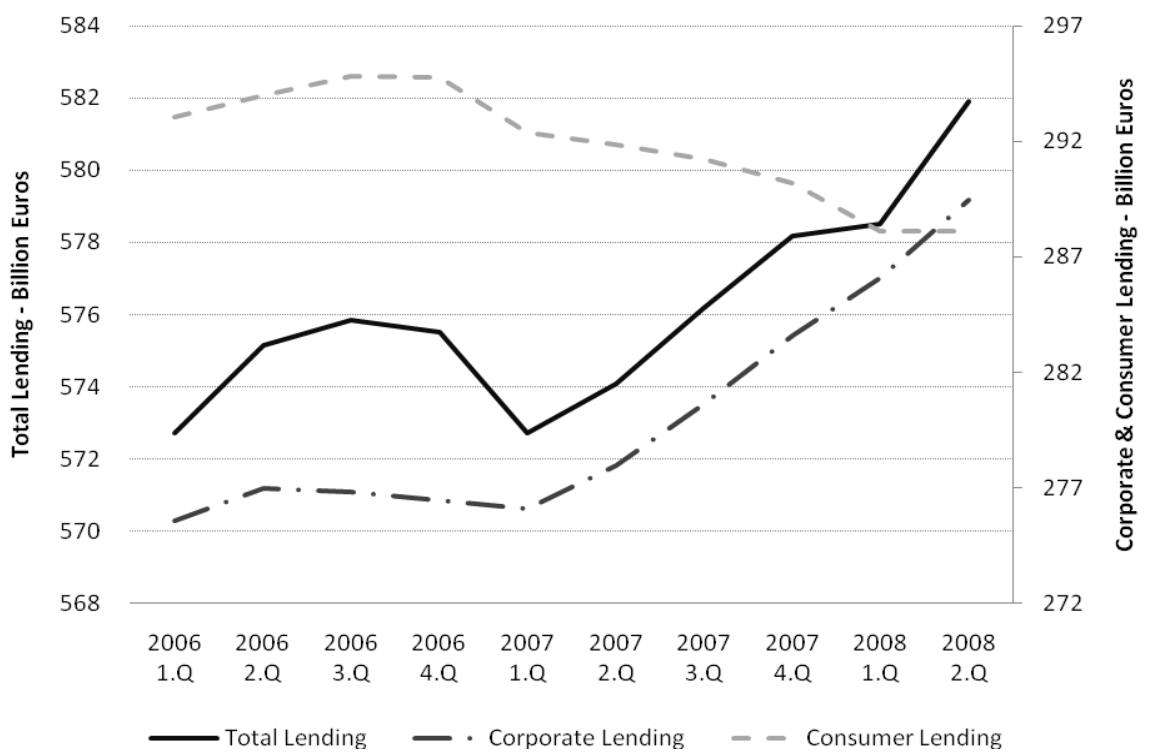


Fig. 2. Geographical reach of affected Landesbanken.

The figure shows the geographical reach of the three Landesbanken that are affected by the financial crisis after August 2007 and during our sample period. They represent Westdeutsche Landesbank or West LB (North Rhine-Westphalia), Bayerische Landesbank or Bayern LB (Bavaria), and Landesbank Sachsen or Sachsen LB (Saxony).

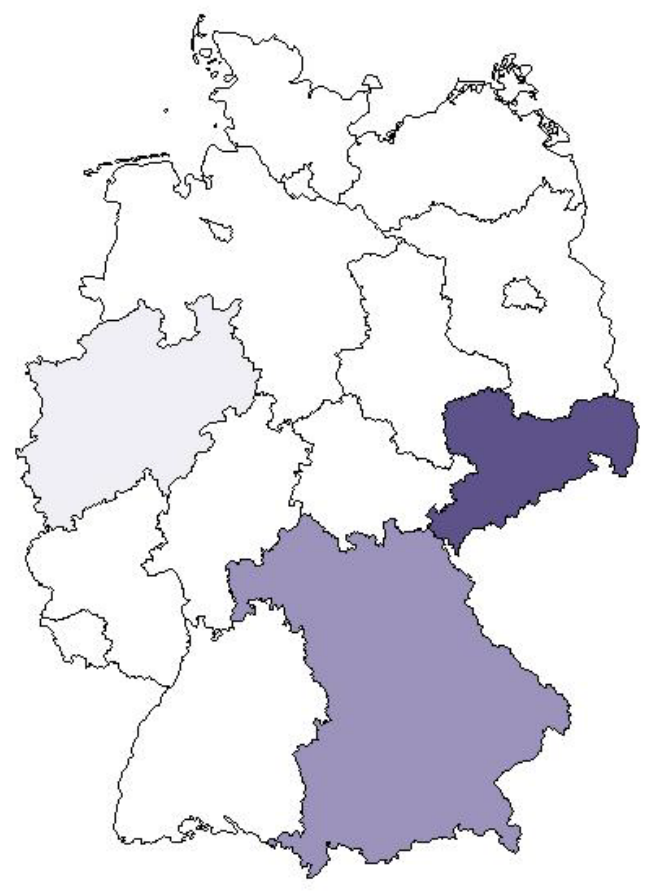

Northrine Westfalia
Bavaria
Saxony 


\section{Table 1}

\section{Ownership structures of Landesbanken}

This table provides an overview of the German Landesbanken and their respective owners. Ownership by savings banks is denoted by (S). The upper part of the table shows the three Landesbanken that are affected by the financial crisis after August 2007 and during our sample period. The lower part shows the remaining eight Landesbanken. The information on the Landesbanken is provided by Bundesverband Öffentlicher Banken Deutschlands VÖB and represents the status as of May 2008.

\begin{tabular}{|c|c|c|}
\hline Landesbank & Owner & Share (percent) \\
\hline \multicolumn{3}{|l|}{ Affected } \\
\hline \multicolumn{3}{|l|}{ Sachsen LB } \\
\hline \multirow[t]{2}{*}{ (acquired by Landesbank Baden-Württemberg on March 6, 2008) } & Sachsen-Finanzgruppe (S) & 62,960 \\
\hline & Freistaat Sachsen & 37,040 \\
\hline \multirow[t]{2}{*}{ Bayern LB } & Freistaat Bayern & 50,000 \\
\hline & Sparkassenverband Bayern (S) & 50,000 \\
\hline \multirow[t]{6}{*}{ West LB } & NRW Bank & 31,200 \\
\hline & Rheinischer Sparkassen- und Giroverband (S) & 25,200 \\
\hline & Westfälisch-Lippischer Sparkassen- und Giroverband (S) & 25,200 \\
\hline & Land Nordrhein-Westfalen & 17,400 \\
\hline & Landschaftsverband Rheinland & 0,500 \\
\hline & Landschaftsverband Westfalen-Lippe & 0,500 \\
\hline \multicolumn{3}{|l|}{ Nonaffected } \\
\hline \multirow[t]{2}{*}{ Bremer Landesbank Kreditanstalt Oldenburg-Girozentrale } & Nord LB & 92,500 \\
\hline & Freie Hansestadt Bremen & 7,500 \\
\hline \multirow[t]{4}{*}{ HSH Nordbank } & Freie und Hansestadt Hamburg & 35,380 \\
\hline & Land Schleswig-Holstein & 19,960 \\
\hline & Sparkassen- und Giroverband für Schleswig-Holstein (S) & 18,050 \\
\hline & J.C. Flowers & 26,610 \\
\hline \multirow[t]{5}{*}{ Landesbank Baden-Württemberg } & Land Baden-Württemberg & 35,611 \\
\hline & Sparkassenverband Baden-Württemberg (S) & 35,611 \\
\hline & Landeshauptstadt Stuttgart & 18,932 \\
\hline & L-Bank, Landeskreditbank Baden-Württemberg & 4,923 \\
\hline & Sparkassen- und Giroverband Rheinland-Pfalz (S) & 4,923 \\
\hline Landesbank Berlin & Landesbank Berlin Holding AG & 100,000 \\
\hline \multirow[t]{3}{*}{ Landesbank Hessen-Thüringen } & Sparkassen- und Giroverband Hessen-Thüringen (S) & 85,000 \\
\hline & Land Hessen & 10,000 \\
\hline & Freistaat Thüringen & 5,000 \\
\hline Landesbank Rheinland-Pfalz & Landesbank Baden-Württemberg & 100,000 \\
\hline \multirow[t]{5}{*}{ Norddeutsche Landesbank } & Land Niedersachsen & 41,750 \\
\hline & Land Sachsen-Anhalt & 8,250 \\
\hline & Sparkassenverband Niedersachsen (S) & 37,250 \\
\hline & Sparkassenbeteiligungsverband Sachsen-Anhalt & 7,530 \\
\hline & Sparkassenbeteiligungszweckverband Mecklenburg-Vorpommern & 5,220 \\
\hline \multirow[t]{3}{*}{ Saar LB } & Bayern LB & 75,100 \\
\hline & Sparkassenverband Saar (S) & 14,900 \\
\hline & Saarland & 10,000 \\
\hline
\end{tabular}




\section{Table 2}

\section{Descriptive Statistics}

This table presents summary statistics for the sample of loan applications from German savings banks from July 2006 through June 2008. The number of observations corresponds to the number of loan applications. Loan amounts are available only for the subset of mortgage loans. The number of weekly loan applications is presented in bank-week units.

\begin{tabular}{|c|c|c|c|c|c|c|c|c|}
\hline & $\begin{array}{c}\text { Number of } \\
\text { observations }\end{array}$ & Mean & $\begin{array}{l}\text { Standard } \\
\text { deviation }\end{array}$ & p(25) & Median & $\mathbf{p}(75)$ & Minimum & Maximum \\
\hline \multicolumn{9}{|l|}{ Inference variables } \\
\hline Affected & $1,296,726$ & 0.365 & 0.481 & 0 & 0 & 1 & 0 & 1 \\
\hline $\begin{array}{l}\text { Post-August } 2007 \\
\text { Affected x Post- }\end{array}$ & $1,296,726$ & 0.493 & 0.500 & 0 & 0 & 1 & 0 & 1 \\
\hline $\begin{array}{l}\text { August } 2007 \\
\text { Nonaffected x Post- }\end{array}$ & $1,296,726$ & 0.180 & 0.385 & 0 & 0 & 0 & 0 & 1 \\
\hline August 2007 & $1,296,726$ & 0.313 & 0.464 & 0 & 0 & 1 & 0 & 1 \\
\hline $\begin{array}{l}\text { Loan type } \\
\text { Mortgage loans }\end{array}$ & $1,296,726$ & 0.285 & 0.452 & 0 & 0 & 1 & 0 & 1 \\
\hline \multicolumn{9}{|l|}{ Dependent variables } \\
\hline Accepted (Yes/No) & $1,296,726$ & 0.956 & 0.205 & 1 & 1 & 1 & 0 & 1 \\
\hline $\begin{array}{l}\text { Loan amount } \\
\text { No. of weekly loan }\end{array}$ & 317,616 & 86,609 & 69,360 & 25,000 & 70,900 & 132,000 & 5,000 & 238,000 \\
\hline applications & 33,685 & 40 & 76 & 11 & 18 & 40 & 11 & 927 \\
\hline \multicolumn{9}{|c|}{ Borrower characteristics } \\
\hline \multicolumn{9}{|c|}{ Relationship characteristics } \\
\hline Relationships & $1,296,726$ & 0.941 & 0.235 & 1 & 1 & 1 & 0 & 1 \\
\hline
\end{tabular}




\section{Table 3}

Aggregate acceptance rates, affected versus nonaffected banks

This table presents aggregate acceptance rates for affected versus nonaffected banks over time. Acceptance rates are aggregated across each quarter. The first Landesbank (Sachsen LB) was directly hit by the financial crisis in August 2007 (Q3-2007). At the same time, the massive exposure and vulnerability of the other Landesbanken (Bayern LB and West LB) also became obvious.

\begin{tabular}{lcc}
\hline \multirow{2}{*}{ Quarter } & \multicolumn{2}{c}{ Aggregate acceptance rate } \\
\cline { 2 - 3 } & Affected banks & Nonaffected banks \\
\hline & & \\
Q3-2006 & $97.34 \%$ & $98.33 \%$ \\
Q4-2006 & 97.58 & 97.85 \\
Q1-2007 & 97.75 & 97.67 \\
Q2-2007 & 97.61 & 97.23 \\
Q3-2007 & 93.96 & 97.52 \\
Q4-2007 & 85.64 & 97.20 \\
Q1-2008 & 84.58 & 97.53 \\
Q2-2008 & 84.93 & 98.03 \\
\hline
\end{tabular}




\section{Table 4}

Loan acceptance rates at the onset of the financial crisis (bivariate tests)

This table presents mean difference-in-differences (DID) estimates of loan acceptance rates. Savings banks are classified into two groups: affected, when savings banks are owner of one of the three Landesbanken that are affected by the US subprime mortgage crisis after August 2007; nonaffected, otherwise. Panels A through C report the results for the pooled sample (consumer and mortgage loans), only consumer loans, and only mortgage loans, respectively. Standard errors are reported in parentheses The number of observations is reported in brackets. The DID estimate is printed in bold. Panel D reports mean DID estimates for the sample segregated by rating class. For brevity, we report only $p$-values of the difference and DID estimates. ${ }^{* * * *}$, ${ }^{* *}$, and ${ }^{*}$ denote significance at the $1 \%, 5 \%$, and $10 \%$ level, respectively.

\begin{tabular}{|c|c|c|c|c|}
\hline $\begin{array}{l}\text { Panel A: Pooled consumer } \\
\text { and mortgage loans }\end{array}$ & All & Affected & Nonaffected & Difference \\
\hline Before August 2007 & $\begin{array}{c}0.976 \\
(0.0002) \\
{[657,309]}\end{array}$ & $\begin{array}{c}0.975 \\
(0.0003) \\
{[239,644]}\end{array}$ & $\begin{array}{c}0.977 \\
(0.0002) \\
{[417,665]}\end{array}$ & $\begin{array}{l}0.002^{* * *} \\
(0.0004)\end{array}$ \\
\hline After August 2007 & $\begin{array}{c}0.943 \\
(0.0003) \\
{[639,417]}\end{array}$ & $\begin{array}{c}0.864 \\
(0.0007) \\
{[233,968]}\end{array}$ & $\begin{array}{c}0.976 \\
(0.0002) \\
{[405,449]}\end{array}$ & $\begin{array}{l}0.113^{* * *} \\
(0.0007)\end{array}$ \\
\hline Difference & $\begin{array}{c}-0.041^{* * *} \\
(0.0003)\end{array}$ & $\begin{array}{c}-0.111^{* * *} \\
(0.0008)\end{array}$ & $\begin{array}{l}-0.001^{*} \\
(0.0003)\end{array}$ & $\begin{array}{c}-\mathbf{0 . 1 1 0 * * *} \\
(0.000)\end{array}$ \\
\hline \multicolumn{5}{|l|}{ Panel B: Consumer loans } \\
\hline Before August 2007 & $\begin{array}{c}0.978 \\
(0.0002) \\
{[464,399]}\end{array}$ & $\begin{array}{c}0.979 \\
(0.0003) \\
{[183,037]}\end{array}$ & $\begin{array}{c}0.977 \\
(0.0003) \\
{[281,362]}\end{array}$ & $\begin{array}{l}0.002^{* * *} \\
(0.0004)\end{array}$ \\
\hline After August 2007 & $\begin{array}{c}0.936 \\
(0.0004) \\
{[462,426]}\end{array}$ & $\begin{array}{c}0.874 \\
(0.0008) \\
{[186,971]}\end{array}$ & $\begin{array}{c}0.978 \\
(0.0003) \\
{[275,455]}\end{array}$ & $\begin{array}{l}0.104^{* * *} \\
(0.0008)\end{array}$ \\
\hline Difference & $\begin{array}{c}-0.042 * * * \\
(0.0004)\end{array}$ & $\begin{array}{c}-0.105^{* * *} \\
(0.0008)\end{array}$ & $\begin{array}{c}0.001^{*} \\
(0.0004)\end{array}$ & $\begin{array}{l}-\mathbf{0 . 1 0 5 * * *} \\
(0.000)\end{array}$ \\
\hline \multicolumn{5}{|l|}{ Panel C: Mortgage loans } \\
\hline Before August 2007 & $\begin{array}{c}0.976 \\
(0.0002) \\
{[192,910]}\end{array}$ & $\begin{array}{c}0.961 \\
(0.0008) \\
{[56,607]}\end{array}$ & $\begin{array}{c}0.977 \\
(0.0004) \\
{[136,303]}\end{array}$ & $\begin{array}{l}.0163 * * * \\
(0.0009)\end{array}$ \\
\hline After August 2007 & $\begin{array}{c}0.943 \\
(0.0003) \\
{[176,991]}\end{array}$ & $\begin{array}{c}0.824 \\
(0.0018) \\
{[46,997]}\end{array}$ & $\begin{array}{c}0.974 \\
(0.0004) \\
{[129,994]}\end{array}$ & $\begin{array}{l}0.150^{* * *} \\
(0.0018)\end{array}$ \\
\hline Difference & $\begin{array}{c}-0.038 * * * \\
(0.0007)\end{array}$ & $\begin{array}{c}-0.137 * * * \\
(0.0019)\end{array}$ & $\begin{array}{c}-0.003 * * * \\
(0.0006) \\
\end{array}$ & $\begin{array}{c}-\mathbf{0 . 1 3 4} * * * \\
(0.000) \\
\end{array}$ \\
\hline
\end{tabular}


Panel D: Diff-in-diff by rating classes

\begin{tabular}{|c|c|c|c|c|c|c|c|}
\hline \multicolumn{8}{|c|}{ Before August 2007} \\
\hline & $\begin{array}{l}\text { Affected } \\
\text { k (Internal } \\
\end{array}$ & $\begin{array}{l}\text { Nonaffected } \\
\text { ating) }\end{array}$ & $\begin{array}{c}\text { Difference } \\
\text { ( } p \text {-value) }\end{array}$ & Affected & Nonaffected & $\begin{array}{c}\text { Difference } \\
\text { ( } p \text {-value) }\end{array}$ & $\begin{array}{c}\text { Diff-in-Diff } \\
(p \text {-value })\end{array}$ \\
\hline \multirow[t]{2}{*}{1} & 0.986 & 0.993 & 0.007 & 0.876 & 0.993 & 0.117 & 0.110 \\
\hline & & & $<0.0001$ & & & $<0.0001$ & $<0.0001$ \\
\hline \multirow[t]{2}{*}{2} & 0.988 & 0.989 & 0.000 & 0.889 & 0.989 & 0.100 & 0.099 \\
\hline & & & $(0.726)$ & & & $<0.0001$ & $<0.0001$ \\
\hline \multirow[t]{2}{*}{3} & 0.989 & 0.987 & -0.002 & 0.898 & 0.989 & 0.091 & 0.093 \\
\hline & & & $(0.055)$ & & & $<0.0001$ & $<0.0001$ \\
\hline \multirow[t]{2}{*}{4} & 0.990 & 0.988 & -0.003 & 0.903 & 0.988 & 0.085 & 0.088 \\
\hline & & & $(0.001)$ & & & $<0.0001$ & $<0.0001$ \\
\hline \multirow[t]{2}{*}{5} & 0.988 & 0.987 & 0.000 & 0.890 & 0.987 & 0.097 & 0.097 \\
\hline & & & $(0.607)$ & & & $<0.0001$ & $<0.0001$ \\
\hline \multirow[t]{2}{*}{6} & 0.986 & 0.985 & 0.000 & 0.890 & 0.986 & 0.095 & 0.096 \\
\hline & & & (0.629) & & & $<0.0001$ & $<0.0001$ \\
\hline \multirow[t]{2}{*}{7} & 0.983 & 0.985 & 0.002 & 0.890 & 0.985 & 0.095 & 0.093 \\
\hline & & & $(0.046)$ & & & $<0.0001$ & $<0.0001$ \\
\hline \multirow[t]{2}{*}{8} & 0.978 & 0.981 & 0.003 & 0.870 & 0.980 & 0.110 & 0.107 \\
\hline & & & $(0.005)$ & & & $<0.0001$ & $<0.0001$ \\
\hline \multirow[t]{2}{*}{9} & 0.973 & 0.975 & 0.002 & 0.859 & 0.977 & 0.118 & 0.116 \\
\hline & & & 0.285 & & & $<0.0001$ & $<0.0001$ \\
\hline \multirow[t]{2}{*}{10} & 0.958 & 0.958 & 0.000 & 0.817 & 0.949 & 0.132 & 0.132 \\
\hline & & & 0.841 & & & $<0.0001$ & $<0.0001$ \\
\hline \multirow[t]{2}{*}{11} & 0.885 & 0.917 & 0.032 & 0.715 & 0.904 & 0.189 & 0.157 \\
\hline & & & $<0.0001$ & & & $<0.0001$ & $<0.0001$ \\
\hline \multirow[t]{2}{*}{12} & 0.793 & 0.804 & 0.010 & 0.650 & 0.811 & 0.160 & 0.150 \\
\hline & & & $(0.107)$ & & & $<0.0001$ & $<0.0001$ \\
\hline
\end{tabular}




\section{Table 5}

Loan acceptance rates at the onset of the financial crisis (multivariate tests)

We estimate the probability that a bank accepts a loan application. All variables are defined in the Appendix. The borrower internal rating is the bank's internal risk assessment at the time the loan application is made. The models are estimated using a linear probability model with bank-specific fixed effects and year fixed effects. Panel A reports regression results for the pooled sample (consumer loans and mortgage loans). Panel B reports the results for the consumer loan and mortgage loan subsample. Models 3, 6, and 9 further adjust the standard errors for possible autocorrelation at the bank level. The diagnostic section of Panel A reports the difference-in-differences (DID) estimate as well as the $p$-value from the Wald test under the H0 that the DID estimate is equal to zero. The diagnostic section of Panel B further reports the $p$-value from the Wald test under the HO that, among the owners of the affected Landesbanken, loan applicants for mortgage loans are as likely to be accepted as applicants for consumer loans after the start of the financial crisis. Intercept, bank, and year fixed effects are not shown. Heteroskedasticity consistent standard errors are shown in parentheses. ${ }^{* * *},{ }^{* *}$, and ${ }^{*}$ denote significance at the $1 \%, 5 \%$, and $10 \%$ level, respectively.

\begin{tabular}{|c|c|c|c|c|c|c|}
\hline \multicolumn{7}{|c|}{ Panel A: Pooled sample (consumer and mortgage loans) } \\
\hline & \multicolumn{6}{|c|}{ Consumer and mortgage loans } \\
\hline & \multicolumn{2}{|c|}{$(1)$} & \multicolumn{2}{|c|}{$(2)$} & \multicolumn{2}{|c|}{ (3) } \\
\hline (1) Affected x Post-August 2007 & $-0.071^{* * *}$ & $(0.0008)$ & $-0.072 * * *$ & $(0.0008)$ & $-0.072 * * *$ & $(0.0227)$ \\
\hline (2) Unaffected x Post-August 2007 & $0.011 * * *$ & $(0.0006)$ & $0.010 * * *$ & $(0.0007)$ & $0.010^{*}$ & $(0.0056)$ \\
\hline \multicolumn{7}{|l|}{ Borrower risk (Internal rating) } \\
\hline 1 & $0.228 * * *$ & $(0.0023)$ & $0.228 * * *$ & $(0.0023)$ & $0.228^{* * *}$ & $(0.0269)$ \\
\hline 2 & $0.216^{* * *}$ & $(0.0023)$ & $0.216^{* * *}$ & $(0.0023)$ & $0.216^{* * *}$ & $(0.0257)$ \\
\hline 3 & $0.209 * * *$ & $(0.0022)$ & $0.209 * * *$ & $(0.0022)$ & $0.209 * * *$ & $(0.0248)$ \\
\hline 4 & $0.207 * * *$ & $(0.0022)$ & $0.207 * * *$ & $(0.0022)$ & $0.207^{* * *}$ & $(0.0246)$ \\
\hline 5 & $0.203^{* * *}$ & $(0.0022)$ & $0.203^{* * *}$ & $(0.0022)$ & $0.203^{* * *}$ & $(0.0243)$ \\
\hline 6 & $0.200^{* * *}$ & $(0.0022)$ & $0.200^{* * *}$ & $(0.0022)$ & $0.200^{* * *}$ & $(0.0243)$ \\
\hline 7 & $0.197 * * *$ & $(0.0022)$ & $0.197 * * *$ & $(0.0022)$ & $0.197 * * *$ & $(0.0242)$ \\
\hline 8 & $0.190 * * *$ & $(0.0022)$ & $0.190 * * *$ & $(0.0022)$ & $0.190 * * *$ & $(0.0239)$ \\
\hline 9 & $0.182^{* * *}$ & $(0.0023)$ & $0.182 * * *$ & $(0.0023)$ & $0.182^{* * *}$ & $(0.0233)$ \\
\hline 10 & $0.157 * * *$ & $(0.0023)$ & $0.157^{* * *}$ & $(0.0023)$ & $0.157^{* * *}$ & $(0.0216)$ \\
\hline 11 & $0.097^{* * *}$ & $(0.0026)$ & $0.097 * * *$ & $(0.0026)$ & $0.097^{* * *}$ & $(0.0147)$ \\
\hline Consumer Confidence & & & $0.001 * * *$ & $(0.0001)$ & 0.0010 & $(0.0007)$ \\
\hline Time fixed effects & \multicolumn{2}{|c|}{ Yes } & \multicolumn{2}{|c|}{ Yes } & \multicolumn{2}{|c|}{ Yes } \\
\hline Bank fixed effects & \multicolumn{2}{|c|}{ Yes } & \multicolumn{2}{|c|}{ Yes } & \multicolumn{2}{|c|}{ Yes } \\
\hline Standard errors clustered at bank level & & & & & \multicolumn{2}{|c|}{ Yes } \\
\hline \multicolumn{7}{|l|}{ Diagnostics } \\
\hline Adj. $R^{2}$ & \multicolumn{2}{|c|}{$21.84 \%$} & \multicolumn{2}{|c|}{$21.84 \%$} & \multicolumn{2}{|c|}{$21.84 \%$} \\
\hline Wald Test: All coefficients $=0$ ( $p$-value) & \multicolumn{2}{|c|}{$<0.0001$} & \multicolumn{2}{|c|}{$<0.0001$} & \multicolumn{2}{|c|}{$<0.0001$} \\
\hline \multicolumn{7}{|l|}{ Difference-in-differences } \\
\hline DID estimate: (1) - (2) & \multicolumn{2}{|c|}{$0.082^{* * *}$} & \multicolumn{2}{|c|}{$0.082^{* * *}$} & \multicolumn{2}{|c|}{$0.082^{* * *}$} \\
\hline Wald test: (1) - (2) [p-value] & \multicolumn{2}{|c|}{$<0.0001$} & \multicolumn{2}{|c|}{$<0.0001$} & \multicolumn{2}{|c|}{$<0.0001$} \\
\hline Number of observations & \multicolumn{2}{|c|}{$1,244,441$} & \multicolumn{2}{|c|}{$1,244,441$} & \multicolumn{2}{|c|}{$1,244,441$} \\
\hline
\end{tabular}


Consumer loans (5)
Mortgage loans

(8)
(1) Affected x Post-August 2007

(2) Unaffected x Post-August 2007

Borrower risk (Internal Rating)

1
2
3
4
5
6
7
8
9
10
11

\section{Consumer Confidence}

Time fixed effects

Bank fixed effects

Standard errors clustered at bank level

Diagnostics

Adj. $\mathrm{R}^{2}$

Wald test: All coefficients $=0$ ( $p$-value $)$

Difference-in-differences

DID estimate: (1) - (2)

Wald test: $(1)=(2)$ [ $p$-value]

Within treatment group:

(B) - (A)

Wald test: (B) - (A) [p-value ]

Number of observations

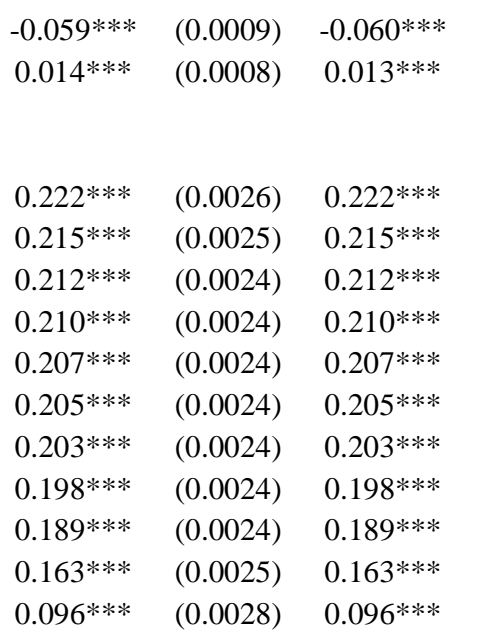

$-0.059 * * *$

$0.014 * * *$

(0.0009)

(0.0008)

$-0.060 * * *$

$\begin{array}{lll}0.222^{* * *} & (0.0026) & 0.222^{* * *} \\ 0.215^{* * *} & (0.0025) & 0.215^{* * *} \\ 0.212^{* * *} & (0.0024) & 0.212^{* * *} \\ 0.210^{* * *} & (0.0024) & 0.210^{* * *} \\ 0.207 * * * & (0.0024) & 0.207 * * * \\ 0.205^{* * *} & (0.0024) & 0.205^{* * *} \\ 0.203^{* * *} & (0.0024) & 0.203^{* * *} \\ 0.198^{* * *} & (0.0024) & 0.198^{* * *} \\ 0.189^{* * *} & (0.0024) & 0.189 * * * \\ 0.163 * * * & (0.0025) & 0.163 * * * \\ 0.096 * * * & (0.0028) & 0.096 * * *\end{array}$

(0.0009)

(6)

(7)

(0.0008) $0.013^{* *}$

(0.019)

$-0.115^{* * *}$

(0.0026) $0.222 * * *$

(0.0256) $0.215^{* * *}$

(0.0025) $0.215^{* * *}$

$\begin{array}{ll}(0.0024) & 0.212 * * * \\ (0.0024) & 0.210 * * *\end{array}$

$(0.0247) \quad 0.203^{* * *}$

$0.0024) \quad 0.210^{* * *}$

$(0.0243) \quad 0.191^{* * *}$

(0.0024) $0.207^{* * *}$

$0.0241) \quad 0.188 * * *$

$0.0024) \quad 0.205^{* * *}$

$(0.0238) \quad 0.165 * * *$

(0.0024) $0.203^{* * *}$

(0.0237) $0.153^{* * *}$

(0.0024) $0.198^{* * *}$

(0.0024) $0.189 * * *$

$0.132 * * *$

$(0.0025) \quad 0.163^{* * *}$

(0.0231) $0.129 * * *$

(0.0028) $0.096^{* * *}$

(0.016) $0.086^{* * *}$

(0.0022)

$-0.116^{* * *}$

(0.0022)

$-0.116 * * *$

$(0.0457)$
$(0.0089)$

(0.0059) $0.215^{* * *}$

(0.0059) $0.203^{* * *}$

(0.0059)

$0.215^{* * *} \quad(0.0769)$

(0.0059) $0.191^{* * *}$

(0.0059)

$.203 * *$

(0.079)

(0.0059) $0.188^{* * *}$

$(0.0059)$

$0.191 * *$

(0.0785)

(0.0059) $0.176 * * *$

(0.0059

$0.188 * * \quad(0.0785)$

(0.0059) $0.165^{* * *}$

$(0.0059)$

$0.176^{* *}$

(0.0769)

(0.0059) $0.153 * * *$

(0.0059) $0.153 *$

$(0.0747)$

(0.006) $0.132 * * *$

(0.006)

$0.153^{* *}$

(0.0696)

(0.006) $0.129 * * *$

$(0.0064) \quad 0.086 * *$

$(0.0061) \quad 0.109 * * * \quad(0.0388)$

$\begin{array}{ccccc} & 0.001^{* * *} & (0.001) & 0.0010 & (0.0007) \\ \text { Yes } & \text { Yes } & & \text { Yes } & \text { Yes } \\ \text { Yes } & \text { Yes } & & \text { Yes } & \text { Yes }\end{array}$

Yes

Yes

$\begin{array}{cccc}0.001^{* * *} & (0.0002) & 0.0010 & (0.0012) \\ \text { Yes } & & \text { Yes } & \\ \text { Yes } & & \text { Yes } & \\ & & \text { Yes }\end{array}$

\begin{tabular}{|c|c|c|c|c|c|}
\hline $23.17 \%$ & $23.18 \%$ & $23.18 \%$ & $23.88 \%$ & $23.88 \%$ & $23.88 \%$ \\
\hline$<0.0001$ & $<0.0001$ & $<0.0001$ & $<0.0001$ & $<0.0001$ & $<0.0001$ \\
\hline $0.073^{* * *}$ & $0.073 * * *$ & $0.073 * * *$ & $0.122 * * *$ & $0.121^{* * *}$ & $0.121 * * *$ \\
\hline \multirow[t]{3}{*}{$<0.0001$} & $<0.0001$ & $<0.0001$ & $<0.0001$ & $<0.0001$ & $<0.0001$ \\
\hline & & & $0.055^{* * *}$ & $0.055^{* * *}$ & $0.055 * * *$ \\
\hline & & & $<0.0001$ & $<0.0001$ & $<0.0001$ \\
\hline 926,825 & 926,825 & 926,825 & 317,616 & 317,616 & 317,616 \\
\hline
\end{tabular}


Table 6

\section{Loan acceptance rates and bank heterogeneity}

We estimate the probability that a bank accepts a loan application. All variables are defined in the Appendix. Log (Bank Size) is the natural logarithm of the bank's asset size in millions of euros. Liquidity (\% of Total Assets) is the ratio of the bank's cash and marketable securities to total assets. The borrower internal rating is the bank's internal risk assessment at the time the loan application is made. The models are estimated using a linear probability model with year fixed effects. Intercept and year fixed effects are not shown. Heteroskedasticity consistent standard errors clustered at the bank level are shown in parentheses. ***, **, and * denote significance at the $1 \%, 5 \%$, and $10 \%$ level, respectively

\begin{tabular}{|c|c|c|c|c|c|c|c|c|c|c|c|c|}
\hline & \multicolumn{12}{|c|}{ Dependent variable: Accepted (Yes/No) } \\
\hline & \multicolumn{12}{|c|}{$\begin{array}{c}\text { Affected banks } \\
\text { (post -August 2007) }\end{array}$} \\
\hline & \multicolumn{2}{|c|}{ Pooled sample } & \multicolumn{2}{|c|}{ Consumer loans } & \multicolumn{2}{|c|}{ Mortgage loans } & \multicolumn{2}{|c|}{ Pooled sample } & \multicolumn{2}{|c|}{ Consumer loans } & \multicolumn{2}{|c|}{ Mortgage loans } \\
\hline & \multicolumn{2}{|c|}{$(\mathbf{1})$} & \multicolumn{2}{|c|}{$(2)$} & \multicolumn{2}{|c|}{ (3) } & \multicolumn{2}{|c|}{ (4) } & \multicolumn{2}{|c|}{ (5) } & \multicolumn{2}{|c|}{ (6) } \\
\hline Log (Bank Size) & $0.049 * * *$ & $(0.016)$ & $0.044 * * *$ & $(0.0156)$ & $0.0794 * * *$ & $(0.0253)$ & & & & & & \\
\hline Liquidity (\% of Total Assets) & & & & & & & $16.149 * * *$ & $(6.311)$ & $13.910 * * *$ & $(5.26)$ & $31.866 * * *$ & $(11.2482)$ \\
\hline \multicolumn{13}{|l|}{ Borrower risk (Internal Rating) } \\
\hline 2 & $0.245^{* * *}$ & $(0.0416)$ & $0.279 * * *$ & $(0.0409)$ & $0.304 * * *$ & $(0.0666)$ & $0.246^{* * *}$ & $(0.0427)$ & $0.278 * * *$ & $(0.0418)$ & $0.290 * * *$ & $(0.0633)$ \\
\hline 3 & $0.254 * * *$ & $(0.0401)$ & $0.267 * * *$ & $(0.0401)$ & $0.298 * * *$ & $(0.067)$ & $0.253^{* * *}$ & $(0.0411)$ & $0.264 * * *$ & $(0.0409)$ & $0.287 * * *$ & $(0.064)$ \\
\hline 4 & $0.260 * * *$ & $(0.0403)$ & $0.264 * * *$ & $(0.0401)$ & $0.333^{* * *}$ & $(0.0676)$ & $0.258 * * *$ & $(0.0411)$ & $0.261 * * *$ & $(0.0409)$ & $0.321 * * *$ & $(0.0645)$ \\
\hline 5 & $0.250 * * *$ & $(0.0393)$ & $0.253 * * *$ & (0.0393) & $0.307 * * *$ & $(0.0648)$ & $0.247 * * *$ & $(0.0401)$ & $0.249 * * *$ & $(0.0401)$ & $0.294 * * *$ & $(0.0623)$ \\
\hline 6 & $0.248 * * *$ & $(0.0388)$ & $0.249 * * *$ & $(0.0386)$ & $0.304 * * *$ & $(0.0658)$ & $0.245^{* * *}$ & $(0.0394)$ & $0.246 * * *$ & $(0.0394)$ & $0.294 * * *$ & $(0.063)$ \\
\hline 7 & $0.250^{* * *}$ & $(0.0391)$ & $0.252 * * *$ & $(0.0392)$ & $0.276^{* * *}$ & $(0.0591)$ & $0.245^{* * *}$ & $(0.0398)$ & $0.247 * * *$ & $(0.0399)$ & $0.260 * * *$ & $(0.0569)$ \\
\hline 8 & $0.229 * * *$ & $(0.0402)$ & $0.230 * * *$ & $(0.0403)$ & $0.268 * * *$ & $(0.0588)$ & $0.225^{* * *}$ & $(0.0406)$ & $0.225 * * *$ & $(0.0409)$ & $0.256^{* * *}$ & $(0.0566)$ \\
\hline 9 & $0.218 * * *$ & $(0.0381)$ & $0.218 * * *$ & (0.0379) & $0.229 * * *$ & $(0.0677)$ & $0.212^{* * *}$ & $(0.0385)$ & $0.213 * * *$ & $(0.0384)$ & $0.224^{* * *}$ & $(0.0641)$ \\
\hline 11 & $0.072^{* * *}$ & $(0.0263)$ & $0.071 * * *$ & $(0.0266)$ & 0.0716 & $(0.0445)$ & $0.071^{* * *}$ & $(0.0268)$ & $0.071 * * *$ & $(0.0272)$ & 0.0570 & $(0.0439)$ \\
\hline Consumer Confidence & 0.0135 & $(0.0099)$ & $0.016^{*}$ & $(0.0096)$ & -0.0076 & $(0.0149)$ & 0.0128 & $(0.0098)$ & 0.0155 & $(0.0096)$ & -0.0082 & $(0.0149)$ \\
\hline Time fixed effects & \multicolumn{2}{|c|}{ Yes } & \multicolumn{2}{|l|}{ Yes } & \multicolumn{2}{|c|}{ Yes } & \multicolumn{2}{|c|}{ Yes } & \multicolumn{2}{|c|}{ Yes } & \multicolumn{2}{|c|}{ Yes } \\
\hline $\begin{array}{l}\text { Standard errors clustered at bank level } \\
\text { Diagnostics }\end{array}$ & \multicolumn{2}{|c|}{ Yes } & \multicolumn{2}{|l|}{ Yes } & \multicolumn{2}{|c|}{ Yes } & \multicolumn{2}{|c|}{ Yes } & \multicolumn{2}{|c|}{ Yes } & \multicolumn{2}{|c|}{ Yes } \\
\hline Adj. $\mathrm{R}^{2}$ & \multicolumn{2}{|c|}{$5.13 \%$} & \multicolumn{2}{|c|}{$5.64 \%$} & 6.9 & & 6.2 & & 6.4 & & 10. & \\
\hline Wald test: All coefficients $=0$ ( $p$-value) & $<0.0$ & & $<0.0$ & & $<0.0$ & & $<0.0$ & & $<0.0$ & & $<0$. & \\
\hline $\begin{array}{l}\text { Mortgage - consumer loans } \\
\Delta[\log (\text { Bank Size })] \text { or }\end{array}$ & & & & & & & & & & & & \\
\hline$\Delta[$ Liquidity (\% of Total Assets) $]$ & & & & & 0.035 & & & & & & 17.96 & $* * *$ \\
\hline$p$-value & & & & & $<0.0$ & & & & & & $<0$ & \\
\hline Number of observations & 207 & 509 & 176, & & 30,8 & & 207, & & 176, & & 30 , & \\
\hline
\end{tabular}




\section{Table 7}

Demand for loans after the onset of the financial crisis (applications)

The dependent variable is the number of loans requested by borrowers each week. We estimate the regressions for the pooled sample (consumer and mortgage loans, Columns 1 and 2) as well as consumer (Columns 3 and 4) and mortgage loans (Columns 5 and 6). The regressions are estimated using a fixed effect ordinary least squares (OLS) model and a negative binomial model with fixed effects to account for the nature of the dependent variable (count data). We further adjust the standard errors for possible autocorrelation at the state level. The diagnostic section of the table reports the difference-in-differences (DID) estimate as well as the $p$-value from the Wald test under the H0 that the DID estimate is equal to zero. The unit of our analysis is the number of weekly loan applications of each single bank and not an individual loan application. This reduces our sample size compared with Table 4 and Table 5. We therefore use the mean internal rating (averaging the internal rating score across all loan applications per bank in a given week) to control for borrower risk. When using the negative binomial model, we further report the likelihood ratio test and in each case reject the H0 that conditional mean and median of the number of weekly loan applications is identical indicating overdispersion. We further do not find an elevated number of zeros in the dependent variable and therefore do not report the regressions using either Poisson or the zero inflated Poisson model. Intercept, bank and year fixed effects are not shown. Heteroskedasticity consistent standard errors are shown in parentheses. ${ }^{* * *},{ }^{* *}$, and ${ }^{*}$ denote significance at the $1 \%$, 5\%, and $10 \%$ level, respectively.

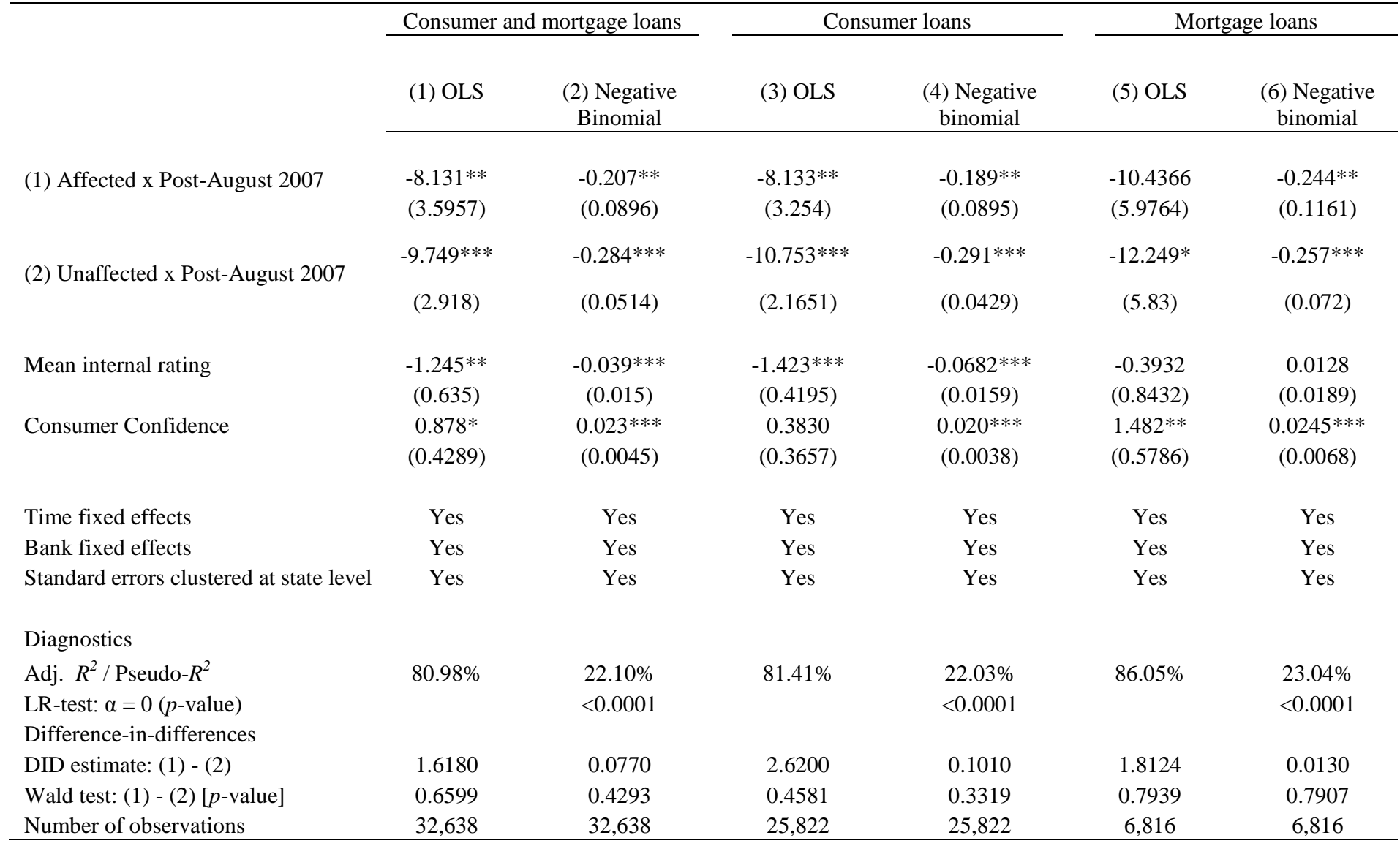




\section{Table 8}

The demand for loans after the onset of the financial crisis (loan amount)

The dependent variable is the natural logarithm of the loan amount requested by the borrower. Loan amounts are available only for the subset of mortgage loans in our sample that corresponds to 317,583 loans. The borrower internal rating is the bank's internal risk assessment at the time the loan application is made. The regressions are estimated using a conditional fixed effect ordinary least squares (OLS) model. Column 3 further adjusts the standard errors for possible autocorrelation at the state level. The diagnostic section of the table reports the DID estimate as well as the p-value from the Wald test under the H0 that the difference-in-differences (DID) estimate is equal to zero. The unit of our analysis is a loan application and not only an accepted loan. Intercept, bank, and year fixed effects are not shown. Heteroskedasticity consistent standard errors are shown in parentheses. ${ }^{* * *},{ }^{* *}$, and ${ }^{*}$ denote significance at the $1 \%, 5 \%$, and10\% level, respectively.

\section{(1) OLS}

$\begin{array}{ll}-0.049 * * * & (0.0091) \\ -0.045^{* * *} & (0.0063) \\ & \\ & \\ -0.595^{* * *} & (0.0146) \\ -0.449 * * * & (0.0154) \\ -0.455^{* * *} & (0.0154) \\ -0.346^{* * *} & (0.0152) \\ -0.298^{* * *} & (0.0151) \\ -0.192^{* * *} & (0.0151) \\ -0.117 * * * & (0.015) \\ -0.087 * * * & (0.015) \\ -0.048^{* * *} & (0.0149) \\ -0.041^{* * *} & (0.015) \\ -0.087 * * * & (0.0159)\end{array}$

Consumer Confidence

Time fixed effects

Bank fixed effects

Standard errors clustered at state level

Diagnostics

Adj. $R^{2}$

Difference-in-differences

DID estimate: (1) - (2)

Wald test: (1) - (2) [p-value]

Number of observations

$14.17 \%$

317,583
(2) OLS

$\begin{array}{llll}-0.049^{* * *} & (0.0092) & -0.0490 & (0.0203) \\ -0.044^{* * *} & (0.0066) & -0.0444 & (0.0211)\end{array}$

$-0.595 * * * \quad(0.0146)$

$-0.595 * * *$

$-0.449 * * * \quad(0.0154)$

$-0.449 * * *$

$-0.455 * * *$

$-0.346 * * *$

$-0.298 * * *$

$-0.192 * * *$

$-0.117 * * *$

$-0.117^{* * *} \quad(0.015)$

$-0.087^{* * *} \quad(0.015)$

$-0.048^{* * *} \quad(0.0149)$

$-0.041^{* * *} \quad(0.015)$

$-0.087^{* * *} \quad(0.0159)$

$-0.048 * * *-(0.0112)$

$-0.041 * * * \quad(0.0134)$

$-0.087^{* * *} \quad(0.0106)$

$-0.0004 \quad(0.0012)$

Yes

Yes

\begin{tabular}{ll}
$-0.0004 \quad(0.0017)$ \\
\hline
\end{tabular}

Yes

Yes

Yes

$14.17 \%$

$14.17 \%$

$\begin{array}{lll}0.0046 & 0.0046 & 0.0046 \\ 0.5762 & 0.5729 & 0.5953\end{array}$

317,583 


\section{Table 9}

Bank-borrower relationships during the financial crisis

We estimate the probability that a bank accepts a loan application. All variables are defined in the Appendix. The borrower internal rating is the bank's internal risk assessment at the time the loan application is made. The models are estimated using a linear probability model with bank specific fixed effects and year fixed effects. Intercept, bank, and year fixed effects are not shown. Heteroskedasticity consistent standard errors are shown in parentheses. ${ }^{* * *},{ }^{* *}$, and ${ }^{*}$ denote significance at the $1 \%, 5 \%$, and $10 \%$ level, respectively.

\begin{tabular}{|c|c|c|c|c|c|c|}
\hline & \multicolumn{6}{|c|}{ Dependent variable: Accepted (Yes/No) } \\
\hline & \multicolumn{2}{|c|}{ Pooled sample } & \multicolumn{2}{|c|}{ Consumer loans } & \multicolumn{2}{|c|}{ Mortgage loans } \\
\hline & (1) LPM & & (2) LPM & & (3) LPM & \\
\hline \multicolumn{7}{|l|}{ Secular effects } \\
\hline Post-August 2007 & $0.011^{* * *}$ & $(0.0006)$ & $0.014^{* * *}$ & $(0.0006)$ & $0.006^{* * *}$ & $(0.0012)$ \\
\hline Relationships & $0.028 * * *$ & $(0.0019)$ & $0.009 * * *$ & $(0.0019)$ & $0.018^{* * *}$ & $(0.0025)$ \\
\hline \multicolumn{7}{|l|}{ Second level interactions } \\
\hline Affected x Post-August 2007 & $-0.081 * * *$ & $(0.0008)$ & $-0.072 * * *$ & $(0.0008)$ & $-0.119 * * *$ & $(0.0022)$ \\
\hline Relationships x Post-August 2007 & $0.004^{* *}$ & $(0.0022)$ & $0.007 *$ & $(0.004)$ & $-0.007 * * *$ & $(0.0027)$ \\
\hline Relationships x Affected & $0.020 * * *$ & $(0.003)$ & $0.016^{* * *}$ & $(0.004)$ & $0.048^{* * *}$ & $(0.005)$ \\
\hline \multicolumn{7}{|l|}{ Diff-in-Diff-in-Diff } \\
\hline Affected x Post-August 2007 x Relationships & $0.049 * * *$ & $(0.005)$ & $0.041^{* * *}$ & $(0.007)$ & $0.018 * *$ & $(0.008)$ \\
\hline \multicolumn{7}{|l|}{ Borrower risk (Internal Rating) } \\
\hline 1 & $0.221 * * *$ & $(0.0023)$ & $0.218^{* * *}$ & $(0.0026)$ & $0.206^{* * *}$ & $(0.0059)$ \\
\hline 2 & $0.210 * * *$ & $(0.0023)$ & $0.212^{* * *}$ & $(0.0025)$ & $0.195^{* * *}$ & $(0.0059)$ \\
\hline 3 & $0.204 * * *$ & $(0.0022)$ & $0.209 * * *$ & $(0.0024)$ & $0.184^{* * *}$ & $(0.0059)$ \\
\hline 4 & $0.202 * * *$ & $(0.0022)$ & $0.207 * * *$ & $(0.0024)$ & $0.182 * * *$ & $(0.0059)$ \\
\hline 5 & $0.198 * * *$ & $(0.0022)$ & $0.203^{* * *}$ & $(0.0024)$ & $0.172^{* * *}$ & $(0.0059)$ \\
\hline 6 & $0.195^{* * *}$ & $(0.0022)$ & $0.202 * * *$ & $(0.0024)$ & $0.162 * * *$ & $(0.0059)$ \\
\hline 7 & $0.193 * * *$ & $(0.0022)$ & $0.200 * * *$ & $(0.0024)$ & $0.151 * * *$ & $(0.0059)$ \\
\hline 8 & $0.187 * * *$ & $(0.0022)$ & $0.196 * * *$ & $(0.0024)$ & $0.131 * * *$ & $(0.0059)$ \\
\hline 9 & $0.180 * * *$ & $(0.0023)$ & $0.188 * * *$ & $(0.0024)$ & $0.128 * * *$ & (0.0059) \\
\hline 10 & $0.155^{* * *}$ & $(0.0023)$ & $0.162 * * *$ & $(0.0025)$ & $0.109 * * *$ & $(0.006)$ \\
\hline 11 & $0.097 * * *$ & $(0.0026)$ & $0.096 * * *$ & $(0.0028)$ & $0.086^{* * *}$ & $(0.0064)$ \\
\hline Time fixed effects & \multicolumn{2}{|c|}{ Yes } & \multicolumn{2}{|c|}{ Yes } & \multicolumn{2}{|c|}{ Yes } \\
\hline Bank fixed effects & \multicolumn{2}{|c|}{ Yes } & \multicolumn{2}{|c|}{ Yes } & \multicolumn{2}{|c|}{ Yes } \\
\hline \multicolumn{7}{|l|}{ Diagnostics } \\
\hline Adj. $R^{2}$ & \multicolumn{2}{|c|}{$22.04 \%$} & \multicolumn{2}{|c|}{$23.25 \%$} & \multicolumn{2}{|c|}{$24.07 \%$} \\
\hline Wald test: All coefficients $=0$ ( $p$-value $)$ & \multicolumn{2}{|c|}{$<0.0001$} & \multicolumn{2}{|c|}{$<0.0001$} & \multicolumn{2}{|c|}{$<0.0001$} \\
\hline \multicolumn{7}{|l|}{ Mortgage - consumer loans } \\
\hline$\Delta[$ Affected x Post-August 2007] & & & & & \multicolumn{2}{|c|}{$0.047^{* * *}$} \\
\hline$p$-value & & & & & \multicolumn{2}{|c|}{$<0.0001$} \\
\hline$\Delta$ [Affected x Post-August 2007 x Relationships] & & & & & \multicolumn{2}{|c|}{$-0.023 * * *$} \\
\hline$p$-value & & & & & \multicolumn{2}{|c|}{$<0.0001$} \\
\hline Number of observations & \multicolumn{2}{|c|}{$1,244,441$} & \multicolumn{2}{|c|}{926,825} & 317 & \\
\hline
\end{tabular}




\section{Table 10}

\section{Compare models for loan supply}

We estimate the probability that a bank accepts a loan application. All variables are defined in the Appendix. This table shows that results from the linear probability model are robust to probit as alternative assumption about the distribution of the error term. We compare the linear probability model and the probit model (with and without fixed effects). We only show the coefficients for the linear probability model as well as the marginal effects for the probit model, respectively, for the interaction of affected and nonaffected banks with post-August 2007. Heteroskedasticity consistent standard errors are shown in parentheses. ${ }^{* * *},{ }^{* *}$, and ${ }^{*}$ denote significance at the $1 \%, 5 \%$, and $10 \%$ level, respectively.

\begin{tabular}{|c|c|c|c|c|c|c|}
\hline & \multicolumn{5}{|c|}{$\begin{array}{l}\text { Dependent variable: } \\
\text { Accepted (Yes/No) }\end{array}$} & \\
\hline & \multicolumn{2}{|c|}{ Pooled sample } & \multicolumn{2}{|c|}{ Consumer loans } & \multicolumn{2}{|c|}{ Mortgage loans } \\
\hline \multicolumn{7}{|l|}{ Linear probability model } \\
\hline (1) Affected x Post-August 2007 & $-0.071 * * *$ & $(0.0008)$ & $-0.059 * * *$ & $(0.0009)$ & $-0.116 * * *$ & $(0.0022)$ \\
\hline (2) Nonaffected x Post -August 2007 & $0.010 * * *$ & $(0.0006)$ & $0.014^{* * *}$ & $(0.0008)$ & $0.005^{* * *}$ & $(0.0012)$ \\
\hline Diff-in-Diff ( $p$-value) & \multicolumn{2}{|c|}{$<0.0001^{* * *}$} & \multicolumn{2}{|c|}{$<0.0001^{* * *}$} & \multicolumn{2}{|c|}{$<0.0001 * * *$} \\
\hline \multicolumn{7}{|l|}{ Probit (without fixed effects) } \\
\hline (1) Affected x Post-August 2007 & $-0.081^{* * *}$ & $(0.0015)$ & $-0.074 * * *$ & $(0.0016)$ & $-0.095 * * *$ & $(0.0035)$ \\
\hline (2) Nonaffected x Post-August 2007 & $0.006 * * *$ & $(0.0006)$ & $0.011 * * *$ & $(0.0006)$ & $0.004^{* * *}$ & $(0.0013)$ \\
\hline Diff-in-Diff ( $p$-value) & \multicolumn{2}{|c|}{$<0.0001^{* * *}$} & \multicolumn{2}{|c|}{$<0.0001^{* * * *}$} & \multicolumn{2}{|c|}{$<0.0001^{* * *}$} \\
\hline \multicolumn{7}{|l|}{ Probit (with fixed effects) } \\
\hline (1) Affected x Post-August 2007 & $-0.034^{* * *}$ & $(0.0009)$ & $-0.025^{* * *}$ & $(0.0009)$ & $-0.067 * * *$ & $(0.0031)$ \\
\hline (2) Nonaffected x Post-August 2007 & $0.004 * * *$ & $(0.0003)$ & $0.005^{* * *}$ & $(0.0003)$ & $0.001 * * *$ & $(0.0007)$ \\
\hline Diff-in-Diff ( $p$-value) & \multicolumn{2}{|c|}{$<0.0001^{* * *}$} & \multicolumn{2}{|c|}{$<0.0001^{* * *}$} & \multicolumn{2}{|c|}{$<0.0001^{* * *}$} \\
\hline
\end{tabular}




\section{Table 11}

\section{Geographic proximity and access to credit}

We estimate the probability that a bank accepts a loan application. All variables are defined in the Appendix. The borrower internal rating is the bank's internal risk assessment at the time the loan application is made. The models are estimated using a linear probability model (LPM) with bank pair-specific fixed effects in Regressions 1 to 3 and a probit model with standard errors clustered at the bank pair level in Regression 4. Heteroskedasticity consistent standard errors are shown in parentheses. ***, **, and * denote significance at the 1\%, 5\%, and 10\% level, respectively.

\begin{tabular}{|c|c|c|c|c|c|c|c|c|}
\hline \multirow{3}{*}{$\begin{array}{l}\text { (1) Affected x Post-August } 2007 \\
\text { (2) Nonaffected x Post-August } 2007 \\
\text { Affected }\end{array}$} & \multicolumn{2}{|c|}{$\begin{array}{c}\text { Pooled sample, } \\
\text { LPM, } \\
\text { Accepted (Yes/No) } \\
\text { (1) }\end{array}$} & \multicolumn{2}{|c|}{$\begin{array}{c}\text { Consumer loans, } \\
\text { LPM, } \\
\text { Accepted (Yes/No) } \\
(2) \\
\end{array}$} & \multicolumn{2}{|c|}{$\begin{array}{c}\text { Mortgage loans, } \\
\text { LPM, } \\
\text { Accepted (Yes/No) } \\
\text { (3) }\end{array}$} & \multicolumn{2}{|c|}{$\begin{array}{c}\text { Pooled sample, } \\
\text { Probit } \\
\text { Accepted (Yes/No) } \\
(4) \\
\end{array}$} \\
\hline & $-0.144 * * *$ & $(0.0022)$ & $-0.114 * * *$ & $(0.0024)$ & $-0.267 * * *$ & $(0.0055)$ & $-0.149 * * *$ & $(0.0737)$ \\
\hline & $0.007 * * *$ & $(0.0024)$ & $0.011^{* * *}$ & $(0.0025)$ & $0.015^{* *}$ & $(0.006)$ & 0.0052 & $(0.0146)$ \\
\hline \multicolumn{9}{|l|}{ Borrower risk (Internal Rating) } \\
\hline 1 & $0.145^{* * *}$ & $(0.0034)$ & $0.185^{* * *}$ & $(0.0053)$ & $0.187 * * *$ & $(0.0138)$ & $0.041^{* * *}$ & $(0.0091)$ \\
\hline 2 & $0.165^{* * *}$ & $(0.0039)$ & $0.187 * * *$ & $(0.0045)$ & $0.188^{* * *}$ & $(0.0142)$ & $0.042 * * *$ & $(0.0074)$ \\
\hline 3 & $0.168 * * *$ & $(0.0035)$ & $0.180 * * *$ & $(0.0036)$ & $0.172 * * *$ & $(0.0143)$ & $0.047 * * *$ & $(0.0082)$ \\
\hline 4 & $0.172 * * *$ & $(0.0033)$ & $0.177 * * *$ & $(0.0034)$ & $0.186^{* * *}$ & $(0.0144)$ & $0.051 * * *$ & $(0.0087)$ \\
\hline 5 & $0.168 * * *$ & $(0.0033)$ & $0.172 * * *$ & $(0.0033)$ & $0.178 * * *$ & $(0.0144)$ & $0.051 * * *$ & $(0.0087)$ \\
\hline 6 & $0.169 * * *$ & $(0.0033)$ & $0.173^{* * *}$ & $(0.0033)$ & $0.163 * * *$ & $(0.0146)$ & $0.053^{* * *}$ & $(0.0089)$ \\
\hline 7 & $0.168 * * *$ & $(0.0033)$ & $0.171^{* * *}$ & $(0.0033)$ & $0.160 * * *$ & $(0.0149)$ & $0.053^{* * *}$ & $(0.0092)$ \\
\hline 8 & $0.154^{* * *}$ & $(0.0033)$ & $0.156^{* * *}$ & $(0.0033)$ & $0.137 * * *$ & $(0.0153)$ & $0.048^{* * *}$ & $(0.0079)$ \\
\hline 9 & $0.147^{* * *}$ & $(0.0034)$ & $0.148 * * *$ & $(0.0034)$ & $0.127^{* * *}$ & $(0.0159)$ & $0.045^{* * *}$ & $(0.0076)$ \\
\hline 10 & $0.125^{* * *}$ & $(0.0035)$ & $0.128 * * *$ & $(0.0035)$ & $0.059 * * *$ & $(0.017)$ & $0.038 * * *$ & $(0.0077)$ \\
\hline 11 & $0.066^{* * *}$ & $(0.0038)$ & $0.067 * * *$ & $(0.0037)$ & $0.046^{* * *}$ & $(0.0188)$ & $0.022 * * *$ & $(0.0054)$ \\
\hline Consumer Confidence & -0.0010 & $(0.0004)$ & -0.0005 & $(0.0004)$ & -0.0002 & $(0.001)$ & -0.0011 & $(0.0038)$ \\
\hline Time fixed effects & \multicolumn{2}{|c|}{ Yes } & \multicolumn{2}{|c|}{ Yes } & \multicolumn{2}{|c|}{ Yes } & \multicolumn{2}{|c|}{ Yes } \\
\hline Pairwise fixed effects & \multicolumn{2}{|c|}{ Yes } & \multicolumn{2}{|c|}{ Yes } & \multicolumn{2}{|c|}{ Yes } & \multirow{2}{*}{\multicolumn{2}{|c|}{ Yes }} \\
\hline Standard errors clustered at bank pair & & & & & & & & \\
\hline \multicolumn{9}{|l|}{ Diagnostics } \\
\hline Adj. $R^{2}$ & \multicolumn{2}{|c|}{$10.30 \%$} & \multicolumn{2}{|c|}{$9.87 \%$} & \multicolumn{2}{|c|}{$17.80 \%$} & \multicolumn{2}{|c|}{$19.24 \%$} \\
\hline Number of Clusters & \multicolumn{2}{|c|}{31} & \multicolumn{2}{|c|}{31} & \multicolumn{2}{|c|}{30} & \multicolumn{2}{|c|}{31} \\
\hline Wald test: All coefficients = 0 ( $p$-value $)$ & \multicolumn{2}{|c|}{$<0.0001$} & \multicolumn{2}{|c|}{$<0.0001$} & \multicolumn{2}{|c|}{$<0.0001$} & \multicolumn{2}{|c|}{$<0.0001$} \\
\hline \multicolumn{9}{|l|}{ Difference-in-differences } \\
\hline DID estimate: (1) - (2) & \multicolumn{2}{|c|}{$0.151^{* * *}$} & \multicolumn{2}{|c|}{$0.103^{* * *}$} & \multicolumn{2}{|c|}{$0.252 * * *$} & 0.15 & $* * *$ \\
\hline Wald test: (1) - (2) [p-value] & $<0.0$ & 001 & $<0.0$ & 01 & $<0.0$ & 01 & $<0.0$ & 01 \\
\hline Number of observations & 206 & 883 & 171 & & 34 & & 206 & 83 \\
\hline
\end{tabular}




\section{Table 12}

Public announcements of subprime losses

We estimate the probability that a bank accepts a loan application. All variables are defined in the Appendix. The borrower internal rating is the bank's internal risk assessment at the time the loan application is made. The models are estimated using a linear probability model with bank-specific fixed effects and year fixed effects. In Models 1 to 4 we include Sachsen LB, West LB, and Bayern LB in the group of affected banks and identify the following quarters in which the announcements have been made: Sachsen LB: Q3-2007, West LB: Q4-2007, and Bayern LB: Q1-2008. In Models 5 to 8, we also include HSH Nordbank and LBBW in the group of affected Landesbanken and define Q2 2008 as the event date when they reported losses. We report only the difference-indifferences (DID) estimate (Affected * Post Public) and triple-diff estimate (Relationships * Affected * Post Public). Heteroskedasticity consistent standard errors are shown in parentheses. ***, **, and * denote significance at the $1 \%, 5 \%$, and $10 \%$ level, respectively.

\begin{tabular}{|c|c|c|c|c|c|c|c|c|}
\hline & $\begin{array}{c}\text { Pooled } \\
(1) \\
\end{array}$ & $\begin{array}{c}\text { Consumer } \\
(2) \\
\end{array}$ & $\begin{array}{c}\text { Mortgages } \\
\text { (3) }\end{array}$ & $\begin{array}{c}\text { Pooled } \\
(4) \\
\end{array}$ & $\begin{array}{r}\text { Pooled } \\
(5) \\
\end{array}$ & $\begin{array}{c}\text { Consumer } \\
(6) \\
\end{array}$ & $\begin{array}{c}\text { Mortgages } \\
\text { (7) }\end{array}$ & $\begin{array}{r}\text { Pooled } \\
(8) \\
\end{array}$ \\
\hline Affected * Post Public & $\begin{array}{c}-0.064 * * * \\
(0.0177)\end{array}$ & $\begin{array}{c}-0.055^{* * *} \\
(0.0158)\end{array}$ & $\begin{array}{c}-0.105^{* * *} \\
(0.0346)\end{array}$ & $\begin{array}{c}-0.102 * * * \\
(0.0045)\end{array}$ & $\begin{array}{c}-0.050 * * * \\
(0.0147)\end{array}$ & $\begin{array}{c}-0.043 * * * \\
(0.0133)\end{array}$ & $\begin{array}{c}-0.079 * * * \\
(0.0248)\end{array}$ & $\begin{array}{c}-0.072 * * * \\
(0.0038)\end{array}$ \\
\hline Relationships * Affected * Post Public & & & & $\begin{array}{c}0.039 * * * \\
(0.0045)\end{array}$ & & & & $\begin{array}{c}0.021^{* * *} \\
(0.0038)\end{array}$ \\
\hline Internal rating & Yes & Yes & Yes & Yes & Yes & Yes & Yes & Yes \\
\hline Consumer Confidence & Yes & Yes & Yes & Yes & Yes & Yes & Yes & Yes \\
\hline Time fixed effects & Yes & Yes & Yes & Yes & Yes & Yes & Yes & Yes \\
\hline Bank fixed effects & Yes & Yes & Yes & Yes & Yes & Yes & Yes & Yes \\
\hline \multicolumn{9}{|l|}{ Diagnostics } \\
\hline Adj. $R^{2}$ & $21.45 \%$ & $22.74 \%$ & $23.36 \%$ & $21.60 \%$ & $21.27 \%$ & $22.59 \%$ & $23.04 \%$ & $21.41 \%$ \\
\hline Wald test: all coefficients $=0$ (p-value) & $<0.0001$ & $<0.0001$ & $<0.0001$ & $<0.0001$ & $<0.0001$ & $<0.0001$ & $<0.0001$ & $<0.0001$ \\
\hline Number of observations & $1,244,441$ & 926,825 & 317,616 & $1,244,441$ & $1,244,441$ & 926,825 & 317,616 & $1,244,441$ \\
\hline
\end{tabular}

